\title{
Liquidity and shadow banking
}

Article

Accepted Version

Creative Commons: Attribution-Noncommercial-No Derivative Works 4.0

Aftab, Z. and Varotto, S. (2019) Liquidity and shadow banking. Journal of International Money and Finance, 99. 102080. ISSN 0261-5606 doi: https://doi.org/10.1016/j.jimonfin.2019.102080 Available at https://centaur.reading.ac.uk/86270/

It is advisable to refer to the publisher's version if you intend to cite from the work. See Guidance on citing.

To link to this article DOI: http://dx.doi.org/10.1016/j.jimonfin.2019.102080

Publisher: Elsevier

All outputs in CentAUR are protected by Intellectual Property Rights law, including copyright law. Copyright and IPR is retained by the creators or other copyright holders. Terms and conditions for use of this material are defined in the End User Agreement.

\section{www.reading.ac.uk/centaur}

\section{CentAUR}

Central Archive at the University of Reading

Reading's research outputs online 


\title{
Liquidity and Shadow Banking
}

\author{
Zary Aftab \\ ICMA Centre \\ Henley Business School \\ University of Reading
}

\author{
Simone Varotto ${ }^{1}$ \\ ICMA Centre \\ Henley Business School \\ University of Reading
}

\begin{abstract}
Using a unique dataset of the detailed portfolio holdings of US money market funds, we study the behaviour of such funds in the context of the European sovereign debt crisis. These important players in the shadow banking sector were particularly vulnerable to liquidity shocks before the introduction of minimum liquidity requirements. We analyse the impact of these requirements and show that they have considerably increased the resilience of prime funds. We also see that prime funds increase their liquidity to counter expected investors' redemptions in crisis periods. However, liquidity does not shelter risky funds from lower inflows.
\end{abstract}

JEL Classification: G01, G23, G28

Keywords: Sovereign Debt Crisis, Shadow Banking, Liquidity, Money Market Fund, Financial Regulation

\footnotetext{
${ }^{1}$ Corresponding author. Address: ICMA Centre, University of Reading, Whiteknights Park, Reading RG6 6BA, United Kingdom, Email: s.varotto@icmacentre.ac.uk, tel, +441189316655.
} 


\section{Introduction}

The global financial crisis has exposed the inherent weaknesses of the shadow banking system. Money-market mutual funds (MMFs), which are a sizeable part of the shadow banking sector, came under increased regulatory scrutiny due to their vulnerability to runs and their systemic risk potential. In response, there have been two waves of regulatory reforms to make the funds more resilient. In this paper, we specifically study the impact of liquidity requirements on the behaviour, resilience and portfolio composition of MMFs.

Money market funds are perceived to be safe because of their ability to provide same-day liquidity and preserve investment value. This has attracted a risk-averse shareholder base which, faced with the possibility of capital losses during the subprime crisis, prompted substantial share redemptions. Prime MMFs were particularly affected due to their higher risk investments in corporate debt instruments. The sizeable outflows from MMFs caused shortterm funding markets to shrink considerably, resulting in a credit crunch. Large-scale government interventions followed (see Fed Board 2009, SEC 2009, and President's Working Group on Financial Markets 2010). These events were repeated, to a lesser extent, during the European sovereign debt crisis. As the Eurozone crisis worsened, concerns mounted about substantial US prime funds' exposure to Eurozone banks. As a consequence, MMF shareholders withdrew approximately $\$ 162$ billion between June and August 2011. The sizeable outflows posed the risk of straining money markets (FSOC 2011). According to Chernenko and Sunderam (2014), these redemptions led to reduced lending to creditworthy non-European issuers. Moreover, McCabe et al. (2013) argue that redemptions from prime funds caused a decrease in the supply of lending to non-financial US firms, thus adversely affecting the economy. In response, the Securities and Exchange Commission (SEC) introduced two reforms. The first, in May 2010, was intended to improve the resilience and transparency of MMFs. This reform required MMFs to increase liquidity, decrease average 
portfolio maturity, understand the behaviour of their investors and adjust their portfolio composition accordingly. After further runs during the sovereign debt crisis in 2011, the SEC introduced a second set of rules in October 2014. These rules impose additional restrictions on liquidity and portfolio concentration, improve reporting requirements and effect structural changes in the MMF industry.

Our contributions to the relevant literature are as follows. First, we collate a unique dataset, which includes detailed portfolio holdings of MMFs before and after the 2010 reform. To the best of our knowledge, this is the first paper to assess the effectiveness of this reform by using detailed pre- and post-reform data. The 2010 reform mandated prime funds to hold at least $10 \%$ and $30 \%$ of their assets in daily and weekly liquid securities ${ }^{2}$, respectively, and restricted the weighted average life (WAL) of their portfolio to be no more than 120 days. We find that the funds for which the new liquidity requirements were binding (constrained funds) reallocated capital that was initially invested in riskier, longer maturity securities to very short-term securities and/or government securities. This leads to a safer asset mix and positions funds to be more resilient to unexpected outflows. Further, following the reform, we determine that portfolio risk declined with a negative impact on the funds' profitability.

Second, with our pre-reform data, we perform a counterfactual analysis to show how the 2010 reform influenced MMFs to adjust their excess liquidity during the sovereign debt crisis. We evaluate changes in daily and weekly excess liquidity for both constrained and unconstrained funds following the reform. We find that constrained funds respond to the reform with a statistically significant increase in excess weekly liquidity. We also find that with the

\footnotetext{
${ }^{2}$ According to the SEC, daily liquid assets include cash, any security that matures within 1 business day or has a demand feature that allows the fund to convert it to cash within 1 business day, and US Treasury securities of any maturity. Weekly liquid assets include cash, any security that matures within 5 business days or has a demand feature that allows the fund to convert it into cash within 5 business days, US government agency securities that mature within 60 days, and US Treasury securities of any maturity.
} 
liquidity levels observed before the reform, $18 \%$ and $29 \%$ of the constrained funds would have lacked enough weekly and daily liquidity, respectively, to cover the redemptions in the worst month of the sovereign debt crisis. Unconstrained funds do not substantially increase either daily or weekly liquidity but still keep higher liquidity levels than constrained funds do. In this respect, unconstrained funds appear to preserve their distinctive features (i.e. higher safety/liquidity) as a way to differentiate themselves from constrained competitors. We conjecture that this may be a strategy to attract wealthy and risk-averse institutional investors.

Third, we test the 'know your investor' requirement of the new 2010 rules, which compels funds to adjust their liquidity levels according to the expected behaviour of their shareholders. We extend previous studies by investigating the impact of expected outflows, as opposed to observed outflows. We show that higher expected outflows lead funds to keep higher liquidity as a precautionary measure. However, such a response is present only in crisis periods when outflows could impair the solvency of the fund.

Fourth, we extend the analysis of Jank and Wedow (2015), who examine the relationship between fund liquidity and inflows for German funds, as well as that of Witmer (2018), who focuses on a similar line of enquiry for US money funds, while also distinguishing between internal and external funds. ${ }^{3}$ With our sample of US prime MMFs, we re-evaluate the role of daily and weekly liquidity in mitigating outflows if a fund's portfolio is perceived to carry considerable credit risk. In the context of the sovereign debt crisis, we use the level of Eurozone bank holdings as a credit risk proxy, as done in previous research (e.g. Chernenko et al. 2014 and Witmer 2018). When the sovereign debt crisis worsened in 2011, the credit default spreads of Eurozone banks started to increase sharply. This caused concerns about the solvency of Eurozone banks, leading to massive withdrawals from exposed funds. Contrary to previous findings, we observe that higher daily and weekly liquidity does not necessarily offer

\footnotetext{
${ }^{3}$ Internal funds are those for which more than $20 \%$ of their shares are beneficially held by affiliated entities.
} 
meaningful protection to risky funds against outflows when markets are unstable. In this sense, investors appear to have overriding concerns about the preservation of capital, even when the funds can more effectively meet redemptions.

The remainder of this paper is organised as follows. In section 2, we briefly introduce shadow banks and MMFs. In section 3, we describe the data. The empirical analysis and results are presented in section 4 . Section 5 concludes the paper.

\section{Institutional Background}

The term 'shadow banking' was coined by McCulley (2007) to collectively describe levered non-bank investment conduits, vehicles and structures. Since the onset of the global financial crisis, academics and policymakers have adopted this term (Pozsar 2008, Adrian and Shin 2009, Gorton and Metrick 2010, FSB 2011, Pozsar et al. 2012). Pozsar et al. (2012) define shadow banks as 'financial intermediaries that conduct credit, maturity, and liquidity transformation without access to central bank liquidity or public-sector credit guarantees ${ }^{4}$. The shadow banking system grew substantially in the years before the Great Recession. Figure 1 shows that the US MMFs alone reached a peak of $\$ 3.83$ trillion in 2008 , which is more than a quarter of total bank assets. In 2018, US shadow banks and banks are similar in size with total financial assets of $\$ 18.27$ trillion dollar and \$19.19 trillion dollar, respectively. ${ }^{5}$ Figure 2 illustrates the importance of MMFs relative to other financial institutions in the commercial paper market. The expansion in the shadow banking sector is attributable to genuine demand (Sunderam 2015), financial innovation, regulatory arbitrage and agency problems in financial markets (Pozsar et al. 2012).

\footnotetext{
${ }^{4}$ Shadow banks include finance companies, asset-backed commercial paper conduits, limited-purpose finance companies, structured investment vehicles, credit hedge funds, money market mutual funds, securities lenders and government-sponsored enterprises.

5 Board of Governors of the Federal Reserve: Financial Accounts of the United States at https://www.federalreserve.gov/datadownload/, the author's own calculations.
} 
We focus on MMFs, a sizeable part of the shadow banking sector. In the United States, MMFs are registered under the Investment Company Act of 1940 and regulated by the SEC under Rule 2a-7. This rule imposes liquidity and diversification requirements, maturity limits, portfolio quality restrictions, enhanced disclosure and stress-testing requirements. Money market funds were established to counter the limits on the interest payable on bank deposits and the limits on the amount of deposits insured. They offered higher interest rates and, by using collateral-based overnight repurchase agreements, they created new instruments that closely resemble insured deposits, but without restrictions on the insured amount. Some researchers consider MMFs as 'narrow banks' that are reliable liquidity providers even in times of crisis (Miles 2001 and Pennacchi 2006). Indeed, from 1983, when SEC Rule 2a-7 was first introduced, to September 2008, when the Reserve Primary Fund lowered its share price below \$1 due to its exposure to Lehman Brothers, only one fund 'broke the buck' in 1994.

Money market mutual funds invest in short-term money market instruments. These funds serve two main purposes. First, they are crucial suppliers of short-term funding and hold large amounts of debt instruments issued by financial and non-financial institutions. Second, they serve as a valuable cash management apparatus for individuals, firms, institutions and governments.

In this paper, we specifically investigate US prime MMFs. These funds are important suppliers of credit to short-term credit markets, particularly because they are not restricted to investing in government securities. Their assets also include repurchase agreements, certificates of deposit, commercial paper and asset-backed commercial paper, bank notes and corporate notes with a remaining maturity of no more than 397 days. Previous crisis episodes have shown that distress in prime MMFs cause disruptions in the short-term credit markets, which are not completely offset by other credit suppliers (Cherenko and Sunderam 2014). 


\section{Data description}

This paper examines detailed portfolio holding reports of MMFs which are filed with the Securities and Exchange Commission monthly (N-MFP), quarterly (N-Q), semi-annually (NCSRS) and annually (N-CSR). These reports are publicly available from the SEC EDGAR database.

The amendments to Rule 2a-7 that were introduced in May 2010 require MMFs to file a monthly report on form N-MFP, which includes a detailed schedule of the portfolio holdings of money funds, starting from November 2010. This form provides information about fundlevel variables such as total net assets, types of share classes, gross yield, and monthly shareholder subscriptions and redemptions. In addition, for each security held, form N-MFP reports the issuer name, amount of principal, yield, legal maturity date, and the CUSIP number. Before November 2010, portfolio holdings are available quarterly. The funds' management companies were required to report portfolio holdings on the N-Q form in the first and third quarters and on the N-CSRS form in the second and fourth quarters. We use three different forms - N-Q, N-CSRS and N-CSR - filed by the funds to build a pre-reform dataset which provides snapshots of portfolio data for each quarter from January to December $2009 .{ }^{6}$ The reporting on these forms, in contrast to N-MFP, is not standardised, and therefore partly requires manual extraction. We then use an algorithm to create a standardised dataset. Restrictions on the WAL and daily/weekly liquidity did not exist before the SEC amendments to Rule 2a-7 in May 2010. As a result, they are not reported on these forms. Therefore, we calculate these variables ourselves (Appendix A.1).

To measure the exposure of prime MMFs to Eurozone banks, which constituted the main source of instability in the summer of 2011 during the sovereign debt crisis, we aggregate

\footnotetext{
${ }^{6} \mathrm{~N}-\mathrm{Q}, \mathrm{N}-\mathrm{CSRS}$ and N-CSR contain information about multiple funds managed by the same management company. We extract only the relevant data for prime MMFs.
} 
issuer-level variables to the parent level. We then assign a country to the parent firm and determine whether the overall exposure to the parent firm is within the Eurozone. For instance, the securities issued by Bank of the West, Fortis Funding LLC, Scaldis Capital LLC, and Starbird Funding Corporation - as well the debt issued by BNP Paribas SA - are all aggregated under the parent company BNP Paribas SA, which is associated with France and treated as a Eurozone exposure. ${ }^{7}$

In addition to a fund's net yield as a measure of portfolio risk, in our robustness tests, we employ a portfolio's expected loss. Following Collins and Gallagher (2016), we calculate the expected loss at maturity $\left(\mathrm{ELM}_{\mathrm{ft}}\right)$ by using the default probabilities for the issuers of the securities held by the fund. Default probabilities are obtained from the Risk Management Institute (RMI) of the National University of Singapore. We match monthly portfolio holdings of prime funds issuer-by-issuer and maturity-by-maturity. ${ }^{8}$

Our final dataset spans from January 2009 to December 2013. We divide the data into a prereform period (January 2009-December 2009) $)^{9,10}$ and a post-reform period (February 2011-

\footnotetext{
${ }^{7}$ The N-MFP form does not specify the country, industry sector of the issuers or their parent company. We collect this information from various other datasets. Since the CUSIP number of the issuers is given, we use it to link the data extracted from the N-MFP forms with other datasets. These include Amadeus, Bankscope, Osiris and Bloomberg as well as the WRDS database for the CUSIP master file.

${ }^{8}$ RMI generates daily forward-looking default probabilities (PDs) for maturities of 1, 3, 6, 12 and 24 months ahead. To match the default probabilities and maximise issuer coverage, we make several assumptions. We linearly interpolate default probabilities to match maturities outside of those provided by the RMI. We also need probabilities for securities with a remaining maturity of less than 1 month. We assume that a security with a remaining maturity of 1 day has no risk; therefore, its probability of default is zero. This allows linearly interpolating between maturities from 1 to 30 days. In addition, we assume that US Treasury, government agency and municipal issuers present minimal risk and, therefore, have a zero probability of default for all maturities. We then match the annualised default probabilities with the parent firms of the issuers obtained from the N-MFP form. The funds for which less than $75 \%$ of their securities can be matched with the default probabilities are removed from the analysis. These represent only $5 \%$ of the funds. On average, $92 \%$ of the total net assets of the prime funds in our sample match default probabilities. Once we obtain all PDs, we use them to calculate the expected loss of a fund portfolio as the value-weighted probability of default of a fund's portfolio multiplied by the loss rate in default.

${ }^{9}$ For this period, only quarterly observations are available for each fund. For each quarter, the snapshot of portfolio holdings is provided for the reporting date. For consistency, other periods are also divided into 4-month periods. ${ }^{10}$ We examine this period for two reasons. First, before Q1 2009 in Q3-Q4 2008, during Lehman's bankruptcy, the funds were in distress. As we want to determine the characteristics of the funds in a normal pre-reform time, we do not consider 2008. Second, we do not use the observations in Q1 2010 because the SEC reform was issued in February 2010. Although it became binding in May 2010 it is possible that the funds brought their level of liquidity and WAL in line with the new requirements before then. Hence, including this period in the analysis could distort the results.
} 
September 2011). The post-reform period is further divided into calm (February 2011-May 2011) and crisis (June 2011 - September 2011) periods. ${ }^{11}$ In our tests, we also consider a calm period after the 2011 crisis (September 2013 - December 2013). (See Figure 3 for a graphical timeline.) Our final dataset excludes feeder funds (i.e. funds that invest in other funds), internal funds, municipal funds and variable annuities, ${ }^{12}$ which gives us a total of 186 prime funds in the post-reform period, with assets totalling $\$ 1.3$ trillion.

We perform extensive sanitation checks and use alternative sources to correct data entry errors. For instance, the net yield provided on form N-MFP is occasionally incorrectly reported by some funds. We obtain the correct values for such funds from Bloomberg. US Treasury bill yields are sourced from the FRED database. The final sample we employ in the analysis is an unbalanced panel. The number of observations varies depending on the variables included in each model and the period of interest.

\section{Empirical Analysis}

As mentioned, the 2010 reform mandated prime money funds to hold at least $30 \%$ of total portfolio assets in weekly liquid securities and $10 \%$ of total portfolio assets in daily liquid assets, and to cap the WAL of the portfolio to 120 days. The liquidity floors are intended to enable prime funds to comfortably meet redemptions in periods of distress. The WAL ceiling protects a fund against interest rate risk and spread risk during high market volatility. To meet these constraints, the funds had to make considerable changes to their portfolios. In this section, we assess the extent of such changes and how they have influenced the liquidity and risk profile of the funds.

\footnotetext{
11 Large MMF redemptions started in June 2011 and continued until September 2011 (Figure 8).

${ }^{12}$ The funds report their type in item 10 of the N-MFP form. We keep the fund in the data if the fund reports itself as 'prime' fund. Item 7 reports whether it is a feeder fund. Variable annuities are reported in item 9. We also exclude two funds that hold only cash over the period from February 2011 to September 2011. If a fund invests more than $95 \%$ in municipal securities, it is dropped from the final dataset.
} 
We separate the funds in our sample into two groups, constrained and unconstrained. Funds are assigned to the constrained group if the weekly liquidity in the final quarter of the beforereform period (2009Q4) is greater than or equal to the required minimum of $30 \%$. Otherwise, they are classified as unconstrained (Figure 4). We use weekly liquidity for the classification because it is the most stringent requirement. ${ }^{13}$ We have 65 constrained funds and 35 unconstrained funds in the before-reform period. Figures 5 and 6 present the distributions of weekly and daily liquidity respectively for constrained and unconstrained funds before and after the reform. As expected, after the reform, constrained funds increase their liquidity, and the difference between the two groups becomes less pronounced. Similarly, Figure 7 illustrates that constrained funds have higher WAL before the reform. However, after the reform, the groups exhibit a similar WAL distribution. We shall now explore the reform-induced portfolio changes in these two groups of funds in more detail.

\subsection{Portfolio Composition Before and After the 2010 Reform}

We examine the extent of changes in funds' daily and weekly liquidity and WAL following the reform. Daily liquid assets, DLiqft, include US Treasury securities of any maturity and any security that can be liquidated within 1 business day (SEC 2010, p.64). Weekly liquid assets,

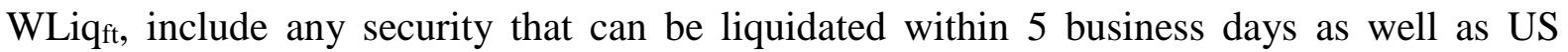
Treasury securities of any maturity and US government agency securities maturing within 60 days. Our DLiq $\mathrm{ft}_{\mathrm{ft}}$ and $\mathrm{WLiq}_{\mathrm{ft}}$ are conservative measures of liquidity because they do not account for the cash holdings of the funds, as they are unavailable for the sample period. We expect DLiq $_{\mathrm{ft}}$ and WLiq $\mathrm{ft}_{\mathrm{ft}}$ to increase in constrained funds and WAL $\mathrm{Lt}_{\mathrm{ft}}$ to decrease, in response to the introduction of liquidity floors and the $\mathrm{WAL}_{\mathrm{ft}}$ ceiling. We decompose weekly liquidity

\footnotetext{
${ }^{13}$ Among the funds that already meet the weekly liquidity requirement in the pre-reform period, all but one also meet the daily requirement. By contrast, more than $50 \%$ of the funds that meet the daily liquidity requirements in the pre-reform period do not meet the weekly requirement. Most pre-reform funds meet the WAL requirement.
} 
holdings into US Treasury securities (Treasuryft), agency securities that mature within 60 days (AgcyLiq ${ }_{\mathrm{ft}}$ ) and liquid assets in the form of short-term securities that can be liquidated within 5 business days (NonGovLiqft).

Table 1 reports the fund averages for liquidity and other variables that describe the portfolio composition of constrained and unconstrained funds before and after the reform. 'Beforereform' is the period from January 2009 to December 2009, for which only quarterly data is available. 'After-reform' is the period from February 2011 to May 2011, for which data are reported monthly. On average, constrained funds have increased their post-reform weekly liquidity by $25.31 \%$ of total portfolio assets, most of which has been achieved by larger holdings of daily liquid assets (14.11\%). The funds have adjusted to higher liquidity by holding slightly more Treasury securities $(+2.82 \%)$ but mostly more short-term non-government securities (+22.41\%), likely due to their higher yield.

Before the reform, the average $\mathrm{WAL}_{\mathrm{ft}}$ is approximately 86 days, which is less than the 120 day ceiling imposed by the reform. This is because, even in the absence of the requirements, fund managers had used WAL limits to reduce portfolio risk (SEC 2010). However, there are several funds that had a WALft. of longer than 120 days. Following the reform, constrained funds have decreased their $\mathrm{WAL}_{\mathrm{ft}}$ by approximately 20 days. They have also considerably increased their investments $(+20.86 \%)$ in short-term securities maturing within three months, $\left(\mathrm{OA}_{0-3 \mathrm{~m}, \mathrm{ft}}\right)$, which is consistent with the large liquidity gains reported previously. To the same effect, constrained MMFs have decreased investments (-7.24\%) in securities that mature from 9 to 13 months, $\left(\mathrm{OA}_{9-13 \mathrm{~m}, \mathrm{ft}}\right)$.

An increase in liquid assets is expected to translate to lower portfolio yields. Thus, we examine the impact of such an increase on the average excess yield of the constrained funds after the reform. As expected, the funds earn a lower excess yield ( $\left.\operatorname{Spread}_{0-3 \mathrm{~m}, \mathrm{ft}}\right)$ on their shortterm investments. In response to such a decrease, it is possible that the funds increased 
investment in higher-yield securities, to compensate for the drop in earnings. We test this hypothesis and derive evidence that the funds, on average, earn a higher excess yield of 36 bps from the investments in longer-dated securities, (Spread9-13m,ft), after the reform. However, the overall PortRisk $\mathrm{ft}$, calculated as the difference between the gross yield of a fund's assets and the 1-month Treasury bill rate, has fallen $(-24.36 \%)$. This indicates that the regulatory changes have indeed put pressure on the funds' profitability. To test whether investors have withdrawn from prime funds because of the lower yields, we examine the variation in the funds' net assets following the reform. We find that the change is slightly negative but not statistically significant.

We now turn to unconstrained funds. We observe that their weekly liquidity also increases but significantly less than for constrained funds. They seem to do so by substituting agency securities with short-term non-government securities which, again, is probably motivated by the higher yield of the latter. Their increase in liquidity is possibly an attempt to differentiate themselves from other riskier prime funds in order to attract risk-averse shareholders who may use MMFs for safe cash parking rather than as investment vehicles. Unconstrained funds, on average, increase the $\mathrm{WAL}_{\mathrm{ft}}$. However, the average remains relatively lower than that of constrained funds. No major differences are found relative to constrained funds on the other portfolio characteristics. Column 8 shows the extent to which constrained and unconstrained funds have become (dis)similar, after the reform. The overall message is that, relative to the before-reform period, the two groups have moved towards similar liquidity levels and risk profiles in the after-reform period. To check if there is any heterogeneity within the constrained and unconstrained groups of funds in their liquidity adjustments following the reform, we look at their pre-post reform quintile differences. Results are reported in Table 2. Interestingly, the constrained funds with the lowest weekly liquidity before the reform (first quintile) appear to settle to a much higher level of liquidity ( $49.49 \%$ of net assets) than the second and third 
quintiles (39.75\% and $36.01 \%$ respectively) after the reform. ${ }^{14}$ The same pattern can be seen for daily liquidity with a new after-reform level for the first quintile of $27.47 \%$ compared to $19.39 \%$ and $18.98 \%$ for the second and third quintiles, respectively. It is as if the most constrained funds (and, hence, the least in line with the new requirements) 'over-reacted' to the new rules relative to some of their less constrained peers. Indeed, after the reform, the largest liquidity differences between constrained and unconstrained funds are found for the second and third quintiles $(15.14 \%$ and $16.68 \%$, respectively, for weekly liquidity, and $15.60 \%$ and $17.54 \%$ for daily liquidity).

For the post-reform period, we perform further tests on the mean differences between the two groups during the calm and crisis sub-periods. As shown in Table 3, consistent with their assumed preference for safety, unconstrained funds keep more liquidity during the crisis period than constrained funds do (column 8).

In summary, we determine that there have been considerable changes in the portfolio composition of MMFs following the reform. These changes have resulted in increased liquidity and positioned funds to be more resilient in times of heavy outflows. This, however, has occurred at the expense of substantially lower portfolio yields.

\subsection{Impact on the Resilience of MMFs}

In the summer of 2011, the sovereign debt crisis worsened and began to spread from Greece, Ireland and Portugal to other Euro area countries. The credit default spreads of Eurozone banks increased sharply amidst concerns over their solvency. Consequently, investors started withdrawing from MMFs due to their holdings of Eurozone bank assets. Chernenko and Sunderam (2014) find that MMFs with greater exposure to Eurozone banks suffered more

\footnotetext{
${ }^{14}$ Portfolio quintiles are determined before the reform and kept unaltered after the reform, for comparative purposes.
} 
outflows. This crisis period provides a setting to test the effectiveness of the 2010 amendments in making funds more resilient. As investors' withdrawals are most prominent for the period from June to September 2011 (Figure 8), we employ this crisis period in our counterfactual analysis.

We construct a counterfactual excess liquidity measure, ExWLiq $\mathrm{ft}_{\mathrm{ft}}\left(\right.$ ExDLiq $\left._{\mathrm{ft}}\right)$, calculated as the lagged weekly (daily) liquidity in excess of average outflows, $\overline{\text { Outflows }_{\text {f,crisis }}}$, during the sovereign debt crisis. Before the reform, this variable captures the amount of excess liquidity that the funds would have maintained during the crisis had they continued to hold the same level of weekly (daily) liquidity prior to the reform. We estimate the following panel fixedeffects model to conduct the analysis:

$$
\operatorname{ExLiq}_{f t}=\alpha+\beta_{1} \operatorname{Reform}_{t}+\beta_{2} \operatorname{Reform}_{t} * \operatorname{Con}_{f}+\beta_{3} \operatorname{Con}_{f}+\gamma X_{f t-1}+\mu_{f}+\varphi_{t}+\varepsilon f t
$$

The dependent variable is excess liquidity, whether weekly or daily. We include fund fixed effects to control for unobserved fund heterogeneity and time fixed effects to control for timevarying aggregate risk factors. Reform $t$ is a dummy variable which takes a value of one for the after-reform crisis (June 2011-September 2011) and zero for the period before the reform (January 2009-December 2009). Con $\mathrm{f}_{\mathrm{f}}$ is a dummy variable which identifies constrained funds. $\mathrm{X}_{\mathrm{ft}-1}$ is a vector of fund-level control variables which includes the standard deviation of net inflows (FlowVol $\left.{ }_{\mathrm{ft}-1}\right)$, portfolio risk (PortRisk $\mathrm{ft}_{-1}$ ) and expected outflows and inflows (ExpOutflowsft-1, ExpInflowsft-1). The variable definitions are reported in Appendix A.1. As ExpOutflowsft-1 and ExpInflows $\mathrm{ft}_{-1}$ are estimated, our results could suffer from generated regressor bias (Pagan 1984). We address this concern by employing bootstrapped standard errors. Table 4 presents our results. The analysis is conducted for a fixed sample of 100 funds for which we have data before as well as after the reform. Panel A contains the results for weekly excess liquidity and Panel B presents those for daily excess liquidity. Following the reform, and while controlling for other factors that may influence the amount of liquidity held 
by the fund, constrained funds have increased their weekly excess liquidity by a substantial $29 \%$ of total portfolio assets (model 1). However, the new level is still statistically significantly lower, $(-21 \%$ of total portfolio assets), than the excess liquidity held by unconstrained funds post-reform (model 3). These results confirm that the money fund industry has become more resilient to sustained pressure from high redemptions, relative to its pre-reform condition. In model 3, we find that larger funds tend to hold lower levels of weekly excess liquidity. This may be because their wider reach among investors enables them to diversify the risk of redemptions with a higher number of subscriptions. In Panel B, we repeat the analysis for daily excess liquidity. The results are broadly confirmed. However, the Wald tests show that constrained funds appear to have adjusted their daily liquidity to such an extent that it is no longer statistically significantly different from that of unconstrained funds after the reform.

We verify whether our findings are robust to the definitions of constrained and unconstrained funds. Figure 4 indicates that some funds are close to the $30 \%$ weekly liquidity threshold we have used to define the two types of funds. Arguably, borderline cases may not be considered to be fully representative of either of the two groups. We therefore eliminate all the borderline funds that lie in the plus or minus $2 \%$ weekly liquidity band around the threshold. Unreported results confirm our previous conclusions. ${ }^{15}$

Table 5 presents the distribution of counterfactual excess liquidity across all funds before and after the reform. ExWLiq $\mathrm{ft}_{\mathrm{ft}}$ and ExDLiq $\mathrm{ft}_{\mathrm{ft}}$ are defined as before. ExWLiq_WC $\mathrm{C}_{\mathrm{ft}}$ $\left(\right.$ ExDLiq_WC $\left.\mathrm{Wf}_{\mathrm{ft}}\right)$ is the worst-case excess weekly (daily) liquidity calculated as the difference between lagged weekly (daily) liquidity and the highest level of monthly net outflows, Outflows $_{\text {f,crisis, }}$ during the sovereign debt crisis (June 2011-September 2011). Panel A shows the distribution of variables for constrained funds. Before the reform, $8 \%$ of fund-month observations would have had negative excess weekly liquidity had the sovereign debt crisis

\footnotetext{
${ }^{15}$ Results are available from the authors on request.
} 
average losses materialised. For the counterfactual excess daily liquidity, $12 \%$ of fund-month observations are negative. These results show that a non-negligible proportion of funds would have experienced a shortfall in liquidity had a sovereign crisis-type of event occurred before the reform period. When we consider the worst-case scenario, the proportion of fund-months with liquidity shortages rises substantially to $18 \%$ and $29 \%$ for weekly and daily liquidity respectively. For unconstrained funds (Panel B), as expected, liquidity shortages are markedly more limited.

After the reform, the situation improves dramatically, with weekly liquidity shortages going to zero even in the worst-case scenario, and daily liquidity shortages affecting only a small proportion of fund-month observations. In Table 5, we also report the proportions of fundmonths where we observe a breach of the minimum liquidity requirements after the reform. We see that in the worst-case scenario, weekly and daily liquidity requirements are breached in $36 \%$ and $27 \%$ of the cases, respectively, for constrained funds, and $24 \%$ and $18 \%$ of the cases for unconstrained funds. These results indicate that although liquidity in the sector has improved and funds have become more resilient following the reform, the sovereign debt crisis put pressure on the liquidity reserves of a non-trivial proportion of funds.

We have also examined actual excess liquidity after the reform, as opposed to the counterfactual levels. Unreported results reveal a lower but still substantial number of funds that did not meet minimum liquidity requirements, and few of them experienced a liquidity shortfall. Specifically, $15 \%$ and $11 \%$ of constrained fund-months are below minimum weekly and daily requirements, which correspond to 22 and 17 funds respectively. By constrast, only $5 \%$ and $7 \%$ of the unconstrained fund-months were below the weekly and daily requirements, respectively, totalling five funds in both cases. One per cent of the constrained fund-months had a liquidity shortfall for a total of three funds. No unconstrained fund had a shortfall. 


\subsection{Factors Influencing Liquidity Holdings}

Following the 2010 reform, MMF management and boards of directors have been required to hold sufficiently liquid securities to meet foreseeable redemptions. This is called the 'know your investors' rule. Depending on the volatility of shareholder redemptions, a fund may need to hold greater liquidity than that required by the daily and weekly minimum levels mandated by the 2010 reform. Consistent with this requirement, and as a precautionary measure to lower the likelihood of falling below the regulatory minimum, most funds in our sample hold more liquidity than the regulatory minimum.

In this section, we assess the factors that influence a fund's liquidity decisions by using the following monthly fixed-effects model,

Liq $_{f t}=\alpha+\beta_{1}$ ExpOutflowsft-1 $+\beta_{2}$ ExpOutflowsft-1 $*$ Crisis $_{t}+\beta_{3}$ ExpInflowsft-1 +

$+\beta_{4}$ ExpInflows $_{f t-1} *$ Crisis $_{t}+\beta_{5}$ PortRisk $_{f t-1}+\beta_{6}$ PortRisk $_{f t-1} *$ Crisis $_{t}+\beta_{7}$ FlowVol $_{f t-1}$

$+\beta_{8}$ Flow Vol $_{f t-1} *$ Crisis $_{t}+\gamma X_{f t-1}+\mu_{f}+\varphi_{t}+\varepsilon_{f t}$

The dependent variable is weekly or daily liquidity, measured as before. The explanatory variables include expected outflows (ExpOutflows $\mathrm{ft}_{\mathrm{ft}}$ ), obtained from an $\mathrm{AR}(1)$ model on past inflows and defined as the negative value of predicted inflows when predicted inflows are negative, and zero otherwise. We also employ expected inflows (ExpInflowsft), which are equal to predicted inflows when they are positive and zero otherwise. We separate expected outflows and expected inflows to account for a possible asymmetry in the fund's liquidity response. In this sense, we depart from the literature in which a historical measure, flow volatility, is often used to analyze the reaction of a fund to the redemption behaviour of its investors (Gallagher et al. 2015 and Witmer 2018). Portfolio risk (PortRisk $\mathrm{ft}_{\mathrm{ft}}$ ) is defined as a fund's gross yield in excess of the 1-month Treasury bill rate. Flow volatility $\left(\right.$ FlowVol $_{\mathrm{ft}}$ ) is the 7-day standard deviation of a fund's inflows and captures the uncertainty in the behaviour of a fund's 
shareholders. $\mathrm{X}_{\mathrm{ft}}$ is a vector of control variables that includes the proportion of a fund's net assets held by institutional shareholders (InstShare $\left.\mathrm{ft}_{\mathrm{t}}\right)$ and the constrained fund dummy $\left(\mathrm{Con}_{\mathrm{f}}\right)$.

As market distress may influence MMFs' liquidity (Jank and Wedow 2015, Jacklin and Bhattacharya 1988), we interact a crisis dummy with the main explanatory variables. The dummy equals one for the crisis period (June 2011 -September 2011) and zero for the postcrisis calm period between September 2013 and December 2013. We examine a post-crisis calm period non-adjacent to the crisis period because we need several months of data to compute portfolio flow volatility (FlowVol $\mathrm{ft}_{\mathrm{ft}}$ ) and want to avoid any overlap between the two periods when constructing explanatory variables.

After the reform, our sample includes 186 funds as compared to 100 funds before the reform. The 86 funds for which we have no pre-reform data are classified as constrained or unconstrained on the basis of the distance of their weekly liquidity from the average weekly liquidity of pre-reform constrained and unconstrained funds (see Appendix A.1 for detailed calculations). In addition, because we estimate the variables ExpOutflows $\mathrm{ft}_{\mathrm{ft}}$ and ExpInflows $\mathrm{ft}$ by using a regression, we calculate bootstrapped standard errors to alleviate second-stage regression bias concerns. Table 6 reports our results. Panel A presents the results for weekly liquidity and Panel B for daily liquidity. We estimate eq. (2) first by using fund fixed effects only (model 1) and then add time fixed effects (model 2). In model 3, we add the constrained fund dummy but exclude fund fixed effects to avoid near multicollinearity between fund fixed effects and the dummy. ${ }^{16}$ Panel A shows that expected outflows do not seem to induce a liquidity response from the funds in the calm period. By contrast, during the crisis, funds with higher expected outflows increase their weekly liquidity levels. This demonstrates that funds with higher redemption risk have a more cautious attitude in stressful times and respond by

\footnotetext{
${ }^{16}$ If we estimate the panel regression in its demeaned form ('within' estimator), all time invariant dummies, such as the constrained fund dummy, would be eliminated. Even if we retain the model in its original form and include fund fixed effects and the constrained fund dummy, the fund fixed effects would closely replicate the dummy because of the short time series dimension of the panel, thus leading to near multicollinearity.
} 
actively adjusting their liquidity levels. This is in line with Witmer (2018) who finds that external prime funds (i.e. those with retail or institutional shareholders) hold more liquidity than do internal prime funds (i.e. those for which the shareholders are the funds owned by the same sponsor), because the former are more vulnerable to runs. While expected outflows have a significant impact on fund liquidity during crisis periods, the coefficient of expected inflows is not statistically significant in any of our specifications. This asymmetric response is plausible as inflows are less likely than outflows to put pressure on a fund to change its portfolio composition.

Next, we see that during normal times, the coefficient of PortRisk $\mathrm{ft}_{\mathrm{ft}}$ is negative in all regressions. This suggests a mechanical relationship between portfolio risk and liquidity, because assets with higher yield are typically less liquid. However, during the crisis, in the full model (model 3), funds with higher portfolio risk exhibit a statistically significant increase in their liquidity, relative to the calm period. The result indicates that riskier funds become more prudent when market conditions deteriorate, and build a liquidity buffer to absorb redemptions. The coefficient of Crisis $t$ is positive and highly significant (model 3). This is plausible because during distress a fund must increase liquidity to service redemptions. Consistent with our previous results, constrained funds are relatively less liquid in normal as well as in crisis times.

Panel B presents the results for daily liquidity. Overall, they are in line with those for weekly liquidity. However, different from previous results, in model 6, expected outflows for the calm period have a negative but weakly significant effect on daily liquidity. The implication is that funds may not be overly concerned about replenishing their very short-term liquidity following redemptions if market conditions are stable. By contrast, the influence of expected outflows on daily liquidity during crisis periods is positive and highly significant, as for weekly liquidity. The Wald test results confirm the above inference. 
Overall, we find that MMFs respond to the behaviour of their investors by adjusting their weekly and daily liquidity, especially in times of crisis. Our findings are broadly confirmed when we introduce a lagged dependent variable. We estimate the resulting dynamic panel with two-step system generalized method of moments (GMM). System GMM controls for fixed effects by using a system of two equations, each of which has its own instruments. The first equation is in levels and is instrumented with lagged differences of the explanatory variables. The second equation is in first differences and is instrumented with lagged levels of the explanatory variables. This method of addressing endogeneity allows assessing time-invariant binary variables, which are removed in within-group estimators. We assess the validity of the instruments by using Hansen $\mathbf{J}$ statistic. The Hansen $\mathbf{J}$ test is based on the null hypothesis that the instruments are not correlated with the error process which, if rejected, would indicate that the instruments are invalid and the estimates inconsistent. We test for first-order autocorrelation and second-order autocorrelation in residuals by using the Arellano-Bond autocorrelation test and use robust standard errors corrected according to Windmeijer (2005). The results are reported in Appendix A.2, Panel A where we use, as in our original regressions, the portfolio yield spread as a measure of risk (PortRisk $\mathrm{ft}_{\mathrm{ft}}$. One caveat of a yield-based measure of credit risk is that it is backward looking. Therefore, we test the robustness of our 'know your investor' analysis by also employing a forward-looking measure, that is, the expected loss at maturity $\left(\mathrm{ELM}_{\mathrm{ft}}\right)$ discussed by Collins and Gallagher (2016). The findings are shown in Appendix A.2 Panel B. Using both measures of portfolio uncertainty, broadly confirms our previous main results, despite some differences. As before, we observe a positive liquidity response when funds expect outflows in a crisis. As for portfolio risk, both PortRisk and ELM are negatively related to weekly and daily liquidity in calm periods. The results are statistically significant except for daily liquidity with ELM specification (model 4). But, such negative relationship between portfolio risk and liquidity may be less pronounced in a crisis period, because funds 
adopt more defensive portfolio decisions to counter potential outflows. This is evidenced by the positive coefficients of PortRisk $\mathrm{ft}_{-1}{ }^{*} \mathrm{Crisis}_{\mathrm{t}}$ and $\mathrm{ELM}_{\mathrm{ft}-1}{ }^{*} \mathrm{Crisis}_{\mathrm{t}}$. However, the crisis effects for these two risk measures do not produce unambiguously statistically significant results for weekly or daily liquidity. In contrast to the static model in Table 6 , the volatility of net inflows in a crisis (FlowVolft-1 $*$ Crisist) is statistically significantly positively related to daily liquidity (models 2 and 4). Therefore, funds appear to increase their very short-term liquidity if they expect greater uncertainty in investors' behaviour which, again, is consistent with a 'know your investor' response by the funds. In addition, expected inflows also become significantly positively related to daily liquidity in a crisis (ExpInflows $\mathrm{ft}_{-1} * \mathrm{Crisis}_{\mathrm{t}}$ in models 2 and 4 ). The result may be plausible with heightened market uncertainty as funds are likely to keep inflows in a highly liquid forms. Wald tests confirm this positive relationship but they are statistically significant only for the ELM $\mathrm{ft}_{\mathrm{ft}}$ specification (model 4), which also yields a mild significantly positive outcome for weekly liquidity (model 3). Finally, the crisis dummy for daily liquidity turns negative and significant, despite being positive and significant in the static model. This may indicate that even though funds may adjust to investors' behaviour, they may experience a decline in their very short-term liquidity in a crisis to meet larger redemptions.

\subsection{Investor Response and Liquidity}

In this section, we examine the redemption behaviour of MMF shareholders in response to the level of fund liquidity. We investigate whether higher liquidity signals health, thereby boosting investor confidence in a fund and providing protection against panic-driven runs. The negative effects of outflows on the remaining investors in a fund is well documented in the literature (e.g. Edelen 1999, Nanda et al. 2000). These negative effects generate a first-mover advantage, ultimately leading to self-fulfilling runs. Jank and Wedow (2015), with a sample of German money funds, show that the funds with higher liquidity have lower outflows in bad times, but also experience lower inflows during good times. In other words, higher liquidity, 
which may result in lower yields, may or may not be attractive to investors depending on market conditions. However, Jank and Wedow (2015) do not differentiate between low- and high-risk funds. It is possible that the level of liquid holdings may be less effective in curbing outflows in a crisis when a fund's portfolio is perceived to be high risk. We extend Jank and Wedow's analysis by studying the role of fund liquidity in tandem with the level of credit risk in the funds. We estimate the following monthly panel fixed-effects regression,

$$
\begin{aligned}
\text { NetInflows } f t_{f t} & \alpha+\beta_{1} \text { EZB }_{f t-1}+\beta_{2} \text { EZB }_{f t-1} * \text { Crisis }_{t}+\beta_{3} \text { WLiq }_{f t-1} \\
& +\beta_{4} \text { WLiq }_{f t-1} * \text { Crisis }_{t}+\beta_{5} \text { Low EZB }_{f t} * \text { WLiq }_{f t-1} * \text { Crisis }_{t} \\
& +\beta_{6} \text { High EZB }_{f t} * \text { WLiq }_{f t-1} * \text { Crisis }_{t}+\gamma X_{f t-1}+\mu_{f}+\varphi_{t}+\varepsilon_{f t}
\end{aligned}
$$

The dependent variable across all regressions is NetInflowsft. We use Eurozone bank exposure, EZB, as a measure of portfolio credit risk. As in Chernenko and Sunderam (2014), we define EZB as the proportion of the total assets of a fund that was invested in the Eurozone banks included in the European Banking Authority's 2011 stress tests. Funds hold, on average, 16\% of their total assets in Eurozone banks during the calm period, with the maximum holding being as high as $40 \%$ (Table 6). For the crisis period, however, we observe an industry-wide drop in Eurozone bank investments. Low EZB $\mathrm{ft}_{\mathrm{ft}}$ and High $\mathrm{EZB}_{\mathrm{ft}}$ are dummies that identify the lowest and highest EZB $\mathrm{B}_{\mathrm{ft}}$ terciles, respectively. WLiq $\mathrm{ft}_{\mathrm{t}-1}$ and Crisist are defined as before. $\mu_{f}$ represents fund fixed effects, and $\varphi_{t}$ denotes time fixed effects. $X_{f t}$ includes control variables that could influence the behaviour of a fund's shareholders. These are: (i) NetYield $\mathrm{ft}_{\mathrm{ft}}$ which is the yield earned by a fund's shareholders and is calculated as the value-weighted average of the 7-day net yields of the fund's share classes as reported on the N-MFP form; (ii) ERatioft, the expense ratio of a fund, calculated as the difference between its gross and net yields; and (iii) InstShare $\mathrm{ft}$, $\mathrm{WAL}_{\mathrm{ft}}, \mathrm{Con}_{\mathrm{f}}$ and Crisist which are defined as before. Standard errors are clustered at the fund level. The sample includes a calm period (February 2011-May 2011) and the crisis period (June 2011- September 2011). 
Table 8 lists the results of using weekly liquidity (Panel A), daily liquidity (Panel B), and the aforementioned controls, to explain net inflows. In line with Chernenko and Sunderam (2014), we find that the funds with higher exposure to Eurozone banks, attract more investors in the calm period because such exposure is more likely to generate higher yields. But, in the crisis period the coefficient of $\mathrm{EZB}_{\mathrm{ft}}$ becomes negative and highly significant. This shows that funds with higher credit risk consistently face higher redemption pressure when markets are unstable.

The coefficients of weekly and daily liquidity ( $\mathrm{WLiq}_{\mathrm{ft}}$ and $\mathrm{DLiq}_{\mathrm{ft}}$ ) are negative, though not statistically significant or only mildly so, during the calm period, depending on the model specification. In other words, lower-yield liquid assets do not attract investors when markets are stable. However, for the crisis period, the coefficients of weekly and daily liquidity (WLiq $\mathrm{ft}-$ ${ }_{1}^{*} \mathrm{Crisis}_{\mathrm{t}}$ and $\left.\mathrm{DLiq}_{\mathrm{ft}-1}{ }^{*} \mathrm{Crisis}_{\mathrm{t}}\right)$ turn positive and are statistically significant in the full models (models 3 and 6). This suggests that investors may consider a fund's liquid assets more desirable in a crisis than in a calm period. The attractiveness of liquid assets may be related to their lower risk and the fact that they may equip a fund more effectively for meeting redemptions. This finding is in line with Jank and Wedow (2015) and Witmer (2018).

The above does not clarify whether the positive influence of liquid assets on inflows in a crisis applies regardless of a fund's risk. If a fund is perceived as being highly risky, its liquidity levels may not help to prevent redemptions. This is what we find when we isolate the influence of the liquidity variables during the crisis for funds with high exposures to Eurozone banks. The coefficient of the term High $\mathrm{EZB}_{\mathrm{ft}-1} * \mathrm{Liq}_{\mathrm{ft}-1} *$ Crisis $_{\mathrm{t}}$ is negative and significant for both weekly and daily liquidity across all specifications. In addition, the Wald test results reaffirm that liquidity is not positively related to inflows in a crisis, as the term Liqft$1^{*}\left(1+\right.$ Crisist $^{*}\left(1+\right.$ High $\left.\left.\mathrm{EZB}_{\mathrm{ft}-1}\right)\right)$ is negative and not statistically significant across all 
specifications (models 1 to 6 ). The implication is that funds are not protected against runs by their liquidity when they are invested in high-risk assets.

This contrasts with Witmer (2018), who finds that riskier funds with higher daily and overnight liquidity have lower redemptions. To determine whether our results are influenced by the observation period and choice of explanatory variables, we estimate eq. (3) by using a longer sample period (January 2011-April 2015) and add the covariates used by Witmer (2018). The results are presented in Appendix A.3. Our previous inference about the impact of liquidity on risky funds in a crisis is confirmed. In addition, the larger sample increases the statistical significance of the regression coefficients and, ultimately, strengthens our conclusions. Surprisingly, the tests based on the extended sample in Table A.3 show that a fund's Eurozone exposures in the calm and crisis periods $\left(\mathrm{EZB}_{\mathrm{ft}-1}\right.$ and $\left.\mathrm{EZB}_{\mathrm{ft}-1} * \mathrm{Crisis}_{\mathrm{t}}\right)$ are no longer significant. This may be because the extended sample is dominated by the post-crisis period, in which Eurozone banks may have lost their attractiveness as an investment. This renders investors' inflows insensitive to $\mathrm{EZB}_{\mathrm{ft}}$ exposure in the extended calm period. A further consequence is that the investors' perceptions about the desirability of $\mathrm{EZB}_{\mathrm{ft}}$ exposure would be more similar in the extended calm period and crisis period; this tallies with the lack of significance of the $\mathrm{EZB}_{\mathrm{ft}-1} *$ Crisist variable.

Consistent with the performance-flow relationship documented in the literature, ${ }^{17}$ in some models we observe that a fund receives higher inflows if it pays higher yields $\left(\right.$ NetYield $\left._{\mathrm{ft}-1}\right)$. However, during the crisis, higher-yield funds do not seem to attract higher inflows. Indeed, Wald tests show that the impact of the net yield on inflows is not significant in a crisis (see the term NetYield $\mathrm{ft}_{\mathrm{f}-1}\left(1+\right.$ Crisis $\left._{\mathrm{t}}\right)$ in both Table 8 and A.3). Our tests in Table A.3 further indicate that the proportion of institutional investors among a fund's shareholders is negative and highly

\footnotetext{
${ }^{17}$ See, for instance, Chernenko and Sunderam (2014), Christoffersen (2001), Christoffersen and Musto (2002), Kacperczyk and Schnabl (2013), Jank and Wedow (2015) and Collins and Gallagher (2016).
} 
significant in a crisis (Institutional_Wit $\left.\mathrm{ft}-1^{*} \mathrm{Crisis}_{\mathrm{t}}\right)^{18}$. This implies that institutional investors may be more reactive to negative news than retail investors, as observed in previous studies (Cherneneko and Sunderam 2014, Gallagher et al. 2015).

\section{Conclusions}

This paper explores the impact of new liquidity requirements designed to improve the stability of MMFs. We show that these requirements have prompted substantial changes in the composition of the funds' portfolios. As expected, portfolio liquidity has increased while asset maturity has declined. This has led to a safer asset mix and equipped funds to withstand high redemption pressure. This finding is corroborated by our counterfactual analysis that examines what would have happened if the funds had maintained the same level of liquidity that they had before the reform. We observe that during the sovereign debt crisis, most MMFs met redemption pressure and had excess liquidity left unused. However, we also find that a nontrivial proportion of funds breached their minimum liquidity requirements to meet outflows. Therefore, given that the liquidity shocks during the sovereign debt crisis were mild relative to the post-Lehman events in 2008, whether MMFs could withstand harsh crisis scenarios remains an open question.

We also see that MMFs seem to be relatively acquainted with the redemption behaviour of their shareholder base and keep higher liquidity when expecting higher redemption pressure. However, investors' withdrawals do not appear to be influenced by the fund liquidity in a crisis if the fund is risky. This suggests that investors' behaviour may be driven more by their concerns about the preservation of capital rather than the funds' ability to meet redemptions.

\footnotetext{
${ }^{18}$ In Table A. 3 we identify institutional funds as those with a minimal investment of $\$ 100,000$, as in Witmer (2018). By contrast, in Table 7 we follow the Chernenko and Sunderam (2014)'s definition which involves using a $\$ 1$ million threshold.
} 
Future research could investigate in greater detail the limitations of higher liquidity in financial markets. Because MMFs are required to hold more liquid assets, banks and corporation will face higher borrowing costs. ${ }^{19}$ This, combined with new SEC reforms that have made prime MMFs less attractive to investors due to, for example, the introduction of discretionary redemption suspensions, may have severe consequences regarding the availability of affordable short-term credit to the private sector. The wider implications of these radical changes in credit markets remain to be explored.

${ }^{19}$ See 'US money market fund reform: an explainer. New rules are already impacting the $\$ 2.7$ tn industry', Financial Times, October 14, 2016. 


\section{References}

Adrian, T. and Shin, H., 2009. The Shadow Banking System: Implications for Financial Regulation. Banque de France Financial Stability Review, 13, pp. 1-10.

Fed Board. 2009. Monetary Policy Report to the Congress. Washington (February 24).

Chernenko, S. and Sunderam, A., 2014. Frictions in shadow banking: Evidence from the lending behavior of money market mutual funds. Review of Financial Studies, 27(6), pp 17171750 .

Christoffersen, S. E. K., 2001. Why do money fund managers voluntarily waive their fees? Journal of Finance. 56, pp.1117-40.

Christoffersen, S. E. K., and D. K. Musto., 2002. Demand curves and the pricing of money management. Review of Financial Studies, 15. pp. 1499-524.

Collins, S., and Gallagher, E. 2016. Assessing the Credit Risk of Money Market Funds during the Eurozone Crisis. Journal of Financial Stability, 25, pp.150-165.

Edelen, R., 1999. Investor flows and the assessed performance of open-end mutual funds. Journal of Financial Economics, 53 (3), pp 439-466.

Financial Stability Oversight Council (FSOC). 2011. Annual Report. Washington.

FSB. 2011. Shadow Banking: Scoping the issues, a background note of the financial stability board. Financial Stability Board.

Gallagher, E., Schmidt, L., Timmermann, A., Wermers, R., 2015. The Stability of Money Market Mutual Funds. The Effect of the 2010 Amendments to Rule 2A-7.

Gorton,G., and Metrick, A., 2010. Regulating the shadow banking system. Brookings Papers on Economic Activity, pp. 261-312.

Jacklin, C.J., Bhattacharya, S., 1988. Distinguishing panics and information basedbank runs: welfare and policy implications. Journal of Political Economy. 96 (3), pp. 568-592.

Jank, S. and Wedow M. 2015. Sturm Und Drang in Money Market Funds: When Money Market Funds Cease to Be Narrow. Journal of Financial Stability, 16, pp. 59-70.

Kacperczyk, M., and P. Schnabl. 2013. How safe are money market funds. Quarterly Journal of Economics, 128, pp. 1073-122.

McCabe, P.E, Cipriani, M., Holscher, M. and Martin, A., 2013. The minimum balance at risk: a proposal to mitigate the systemic risks. Brookings Papers on Economic Activity, pp 211-256.

McCulley, P. 2007. Teton Reflections. PIMCO Global Central Bank Focus

Miles, W., 2001. Can money market mutual funds provide sufficient liquidity to replace deposit insurance? Journal of Economics and Finance, 25(3), pp 328-342. 
Morningstar. 2015. Fee Study: Investors are driving expense ratios down.

Nanda, V., Narayanan, M., Warther, V., 2000. Liquidity, investment ability, and mutual fund structure. Journal of Financial Economics, 57 (3), pp. 417-443.

Pagan, A. 1984. Econometric issues in the analysis of regressions with generated regressors. International Economic Review, 25, pp. 221 - 247.

Pennacchi, G., 2006. Deposit insurance, bank regulation, and financial system risks. Journal of Monetary Economics, 53(1), pp 1-30.

Pozsar, Z., 2008. The Rise and Fall of the Shadow Banking System. Moody's Economy.com.

Pozsar, Z., Adrian, T., Ashcraft, A. and Boesky, H., 2012. Shadow Banking. Federal Reserve Bank of New York, Staff Report no. 458.

President's Working Group on Financial Markets (PWG)., 2010. Report of the president's working group on financial markets: Money market fund reform options. Washington (October 21).

SEC. 2009. Money market fund reform: Proposed rule. Washington (June 30). Release no. IC 2880730.

SEC. 2010. Money Market Fund Reform, Final Rule, Securities and Exchange Commission, Release No. IC-29132.

SEC. 2015. Liquidity and Flows of US Mutual Funds. Division of Economic and Risk Analysis, Staff Report.

Sunderam, A., 2015. Money Creation and the Shadow Banking System. Review of Financial Studies, 28(4) pp. 939-977.

Witmer, J., 2018. Strategic complementarities and money market fund liquidity management. Journal of Financial Intermediation, In Press. 


\section{Figures}

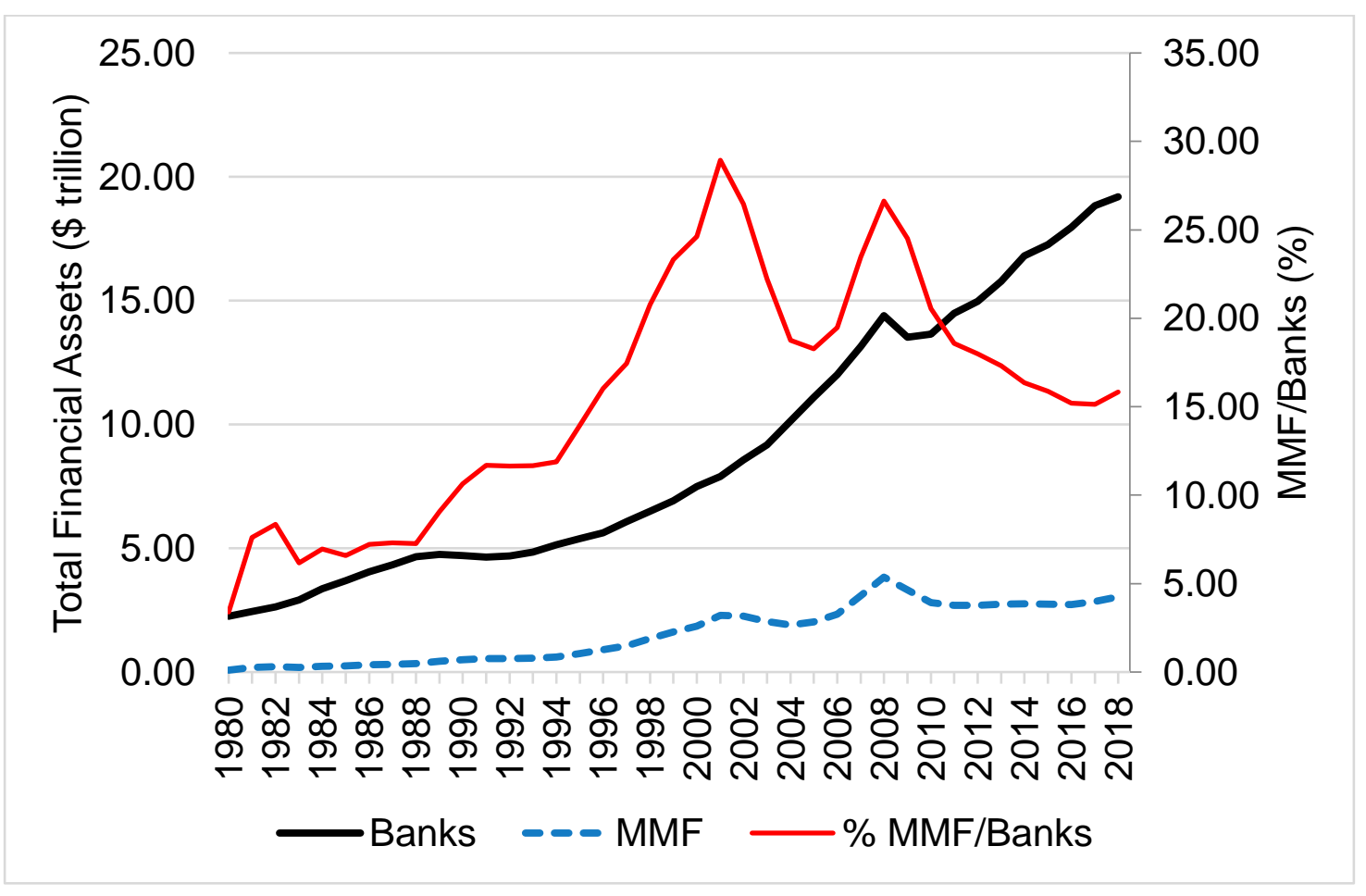

\section{Figure 1: Total Financial Assets: US Data}

This figure shows the total financial assets of US MMFs and the US banks. Banks include the total financial assets of private depository institutions (source: Board of Governors of the Federal Reserve: Financial Accounts of the United States at https://www.federalreserve.gov/datadownload/, and authors' own calculations). 


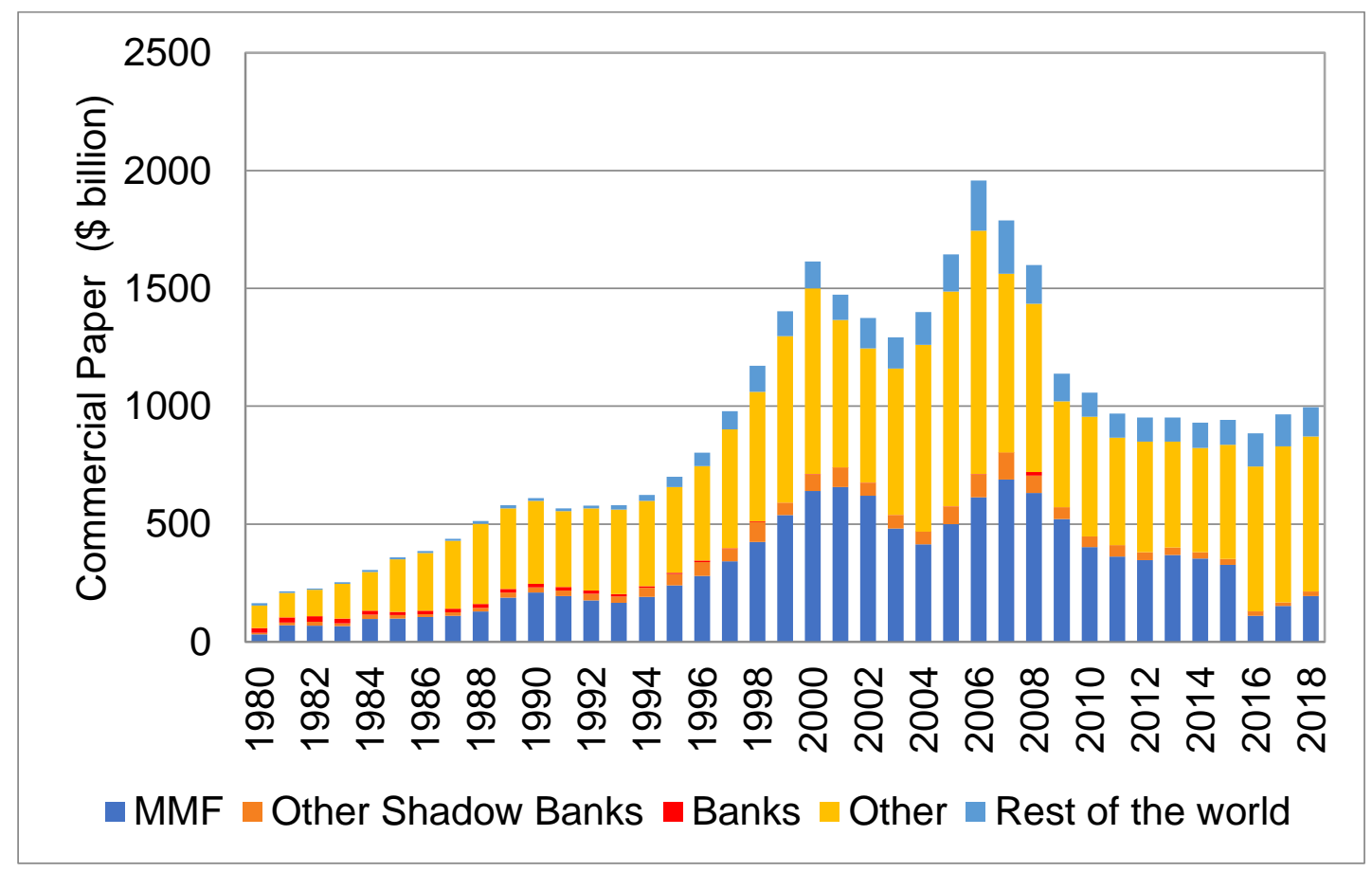

\section{Figure 2: Commercial Paper Holdings: US Data}

This figure shows the amount of commercial paper held by various types of institutions. 'Other shadow banks' include the total financial assets of asset-backed securities issuers, securities brokers and dealers, finance companies, government sponsored enterprises (GSE) and agencies and GSE-backed mortgage pools. 'Banks' include the total financial assets of private depository institutions. 'Other' includes non-profits, retirement and pension funds, life insurance companies and mutual funds. The 'rest of the world' represents the holdings of nonUS investors (source: Board of Governors of the Federal Reserve: Financial Accounts of the United States at https://www.federalreserve.gov/datadownload/, and authors' own calculations). 


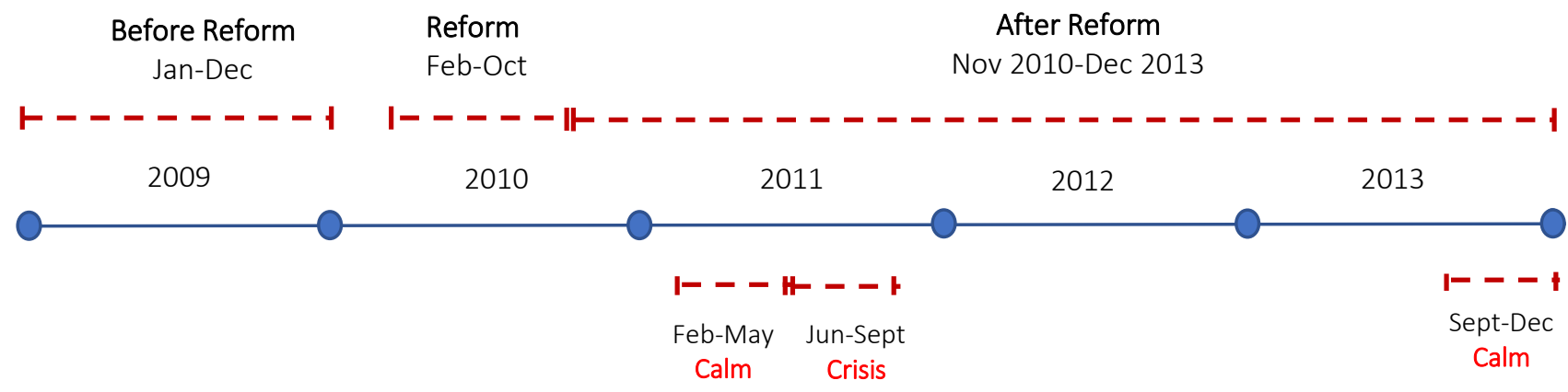

\section{Figure 3: Timeline}

This figure illustrates the various time periods used in the analysis. The reform period starts from the announcement of the SEC reform in February 2010 to their full implementation in November 2010. The afterreform period starts in November 2010, when the N-MFP form data become available, and ends in December 2013. 


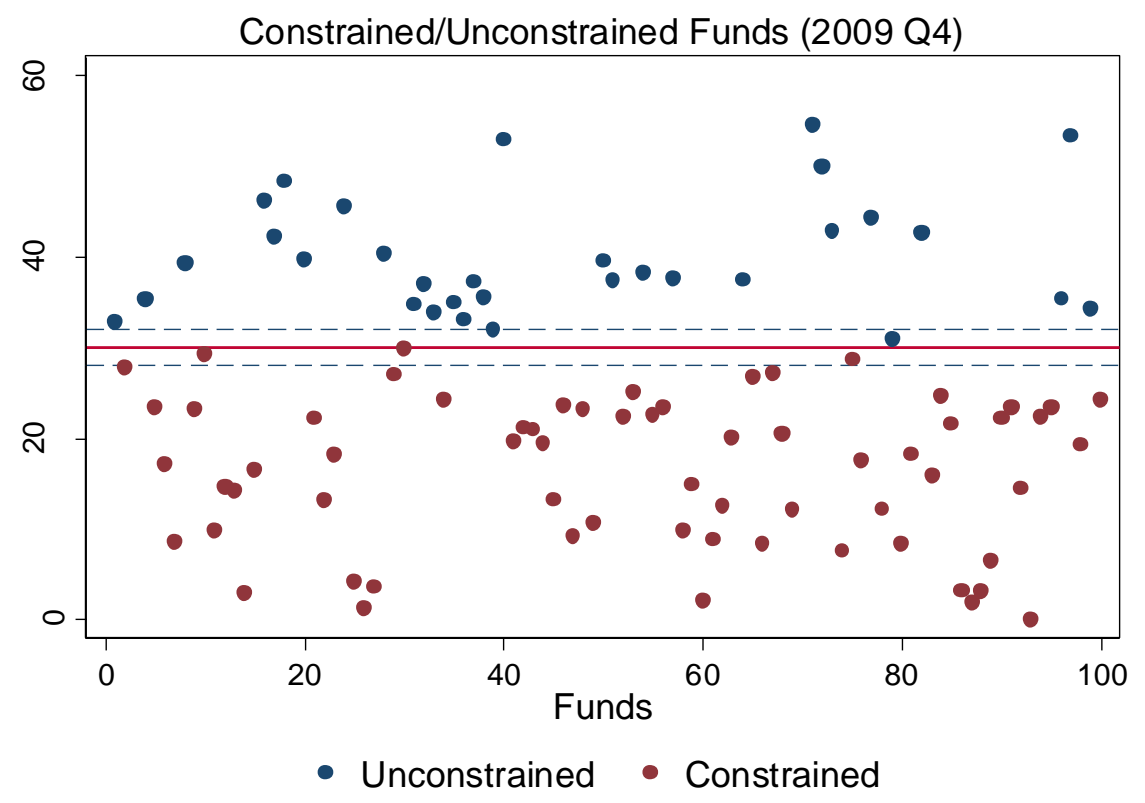

Figure 4: Scatterplot of Weekly Liquidity: Constrained and Unconstrained Funds

This figure presents the scatterplot of funds' weekly liquidity (WLiq $\mathrm{ft}_{\mathrm{t}}$ ) in the final quarter of the before-reform period, 2009Q4. WLiq $\mathrm{ft}$ represents the weekly liquid assets of a fund as a percentage of its total portfolio. It includes any security that matures or has a demand feature that allows it to be converted to cash within 5 business days, US government agency securities that mature within 60 days, and US Treasury securities of any maturity. The horizontal solid red line represents the $30 \%$ regulatory threshold of weekly liquidity, while the dotted blue lines are the $\pm 2 \%$ bands around the regulatory threshold. Funds with weekly liquidity more than or equal to $30 \%$ are classified as unconstrained funds and are represented by navy blue dots, whereas funds with less than $30 \%$ weekly liquidity are classified as constrained funds and are represented by red dots (source: N-Q, N-CSR, and NCSRS forms data, authors' own calculations). 

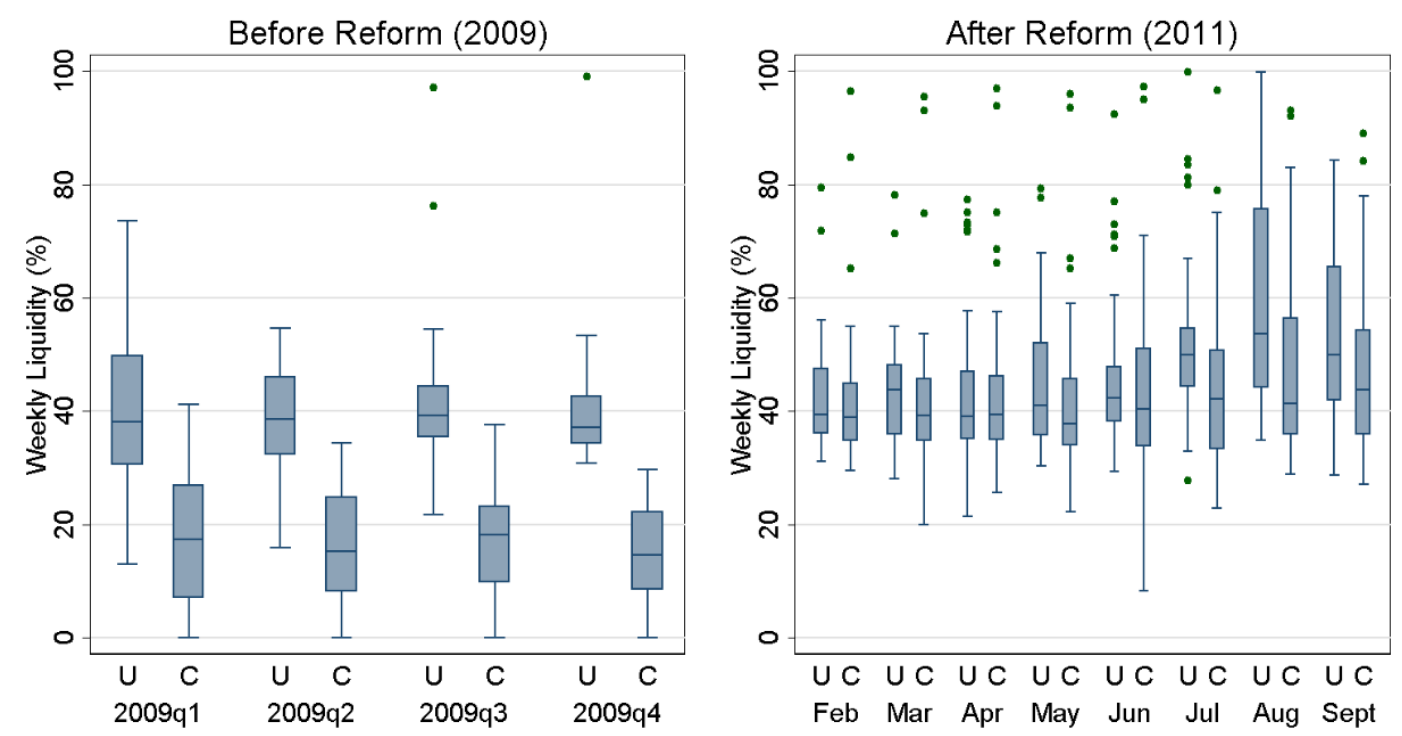

\section{Figure 5: Distribution of Weekly Liquidity Before and After the 2010 Reform}

This figure shows box-and-whisker plots of weekly liquidity (WLiq $\mathrm{ft}_{\mathrm{ft}}$ ) across funds in each quarter of the beforereform period (January 2009-December2009), and in each month of a subsample (February 2011 - September 2011) of the after-reform period. WLiq $\mathrm{ft}_{\mathrm{ft}}$ represents the weekly liquid assets of a fund as a percentage of its total portfolio. It includes any security that matures or has a demand feature that allows it to be converted to cash within 5 business days, US government agency securities that mature within 60 days, and US Treasury securities of any maturity. Constrained funds are the funds that held less than $30 \%$ weekly liquidity before the reform in 2009 Q4. Unconstrained funds are funds that held more than or equal to 30\% weekly liquidity before the reform in 2009Q4. The rectangles show the interquartile range (IQR), which represent the 25th to 75th percentiles, and the horizontal line in the middle of the rectangles is the median. The whiskers below and above the rectangles indicate the lowest and highest weekly liquidity values in the data, respectively, that are not outliers. Outliers are any weekly liquidity values below Q1 $-1.5 *$ IQR or above Q3 + 1.5* IQR. Observations falling outside this range are outliers, denoted with a dot (source: N-Q, N-CSR, N-CSRS and N-MFP forms data, authors' own calculations.) 

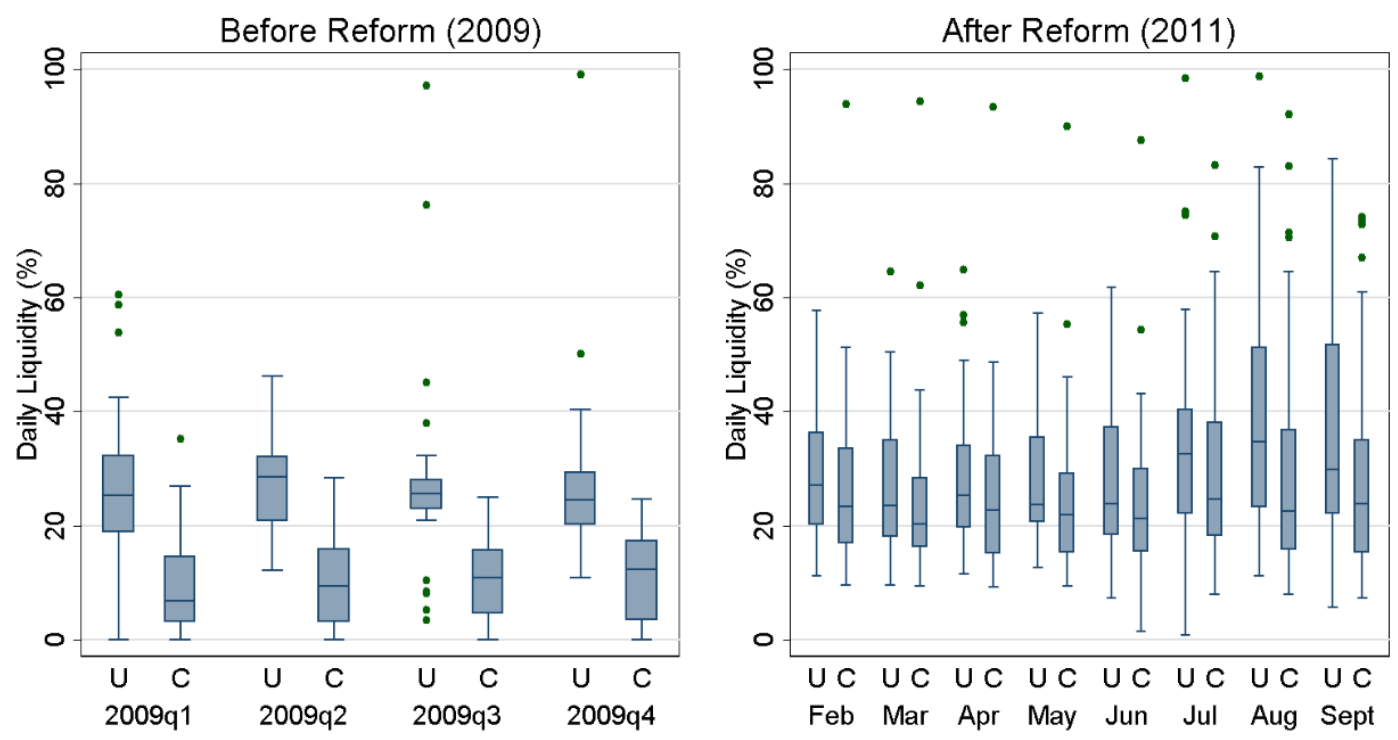

\section{Figure 6: Distribution of Daily Liquidity Before and After the 2010 Reform}

This figure shows box-and-whisker plots of daily liquidity (DLiqft) across funds in each quarter of the beforereform period (January 2009-December 2009), and in each month of a subsample (February 2011- September 2011) of the after-reform period. DLiq $\mathrm{ft}_{\mathrm{t}}$ represents the daily liquid assets of a fund as a percentage of its total portfolio assets. It includes any security that matures or has a demand feature that allows it to be converted to cash within 1 business day and US Treasury securities of any maturity. Constrained funds are funds that held less than $30 \%$ weekly liquidity before the reform in 2009Q4. Unconstrained funds are funds that held more than or equal to $30 \%$ weekly liquidity before the reform in 2009 Q4. The rectangles show the interquartile range (IQR), which represents the 25th to 75th percentiles, and the horizontal line in the middle of the rectangles is the median. The whiskers below and above the rectangles indicate the lowest and highest daily liquidity values in the data, respectively, that are not outliers. Outliers are any daily liquidity values below Q1 $-1.5 *$ IQR or above Q3 +1.5 * IQR. Observations falling outside this range are outliers, denoted with a dot (source: N-Q, N-CSR, N-CSRS and N-MFP forms data, authors' own calculations.) 

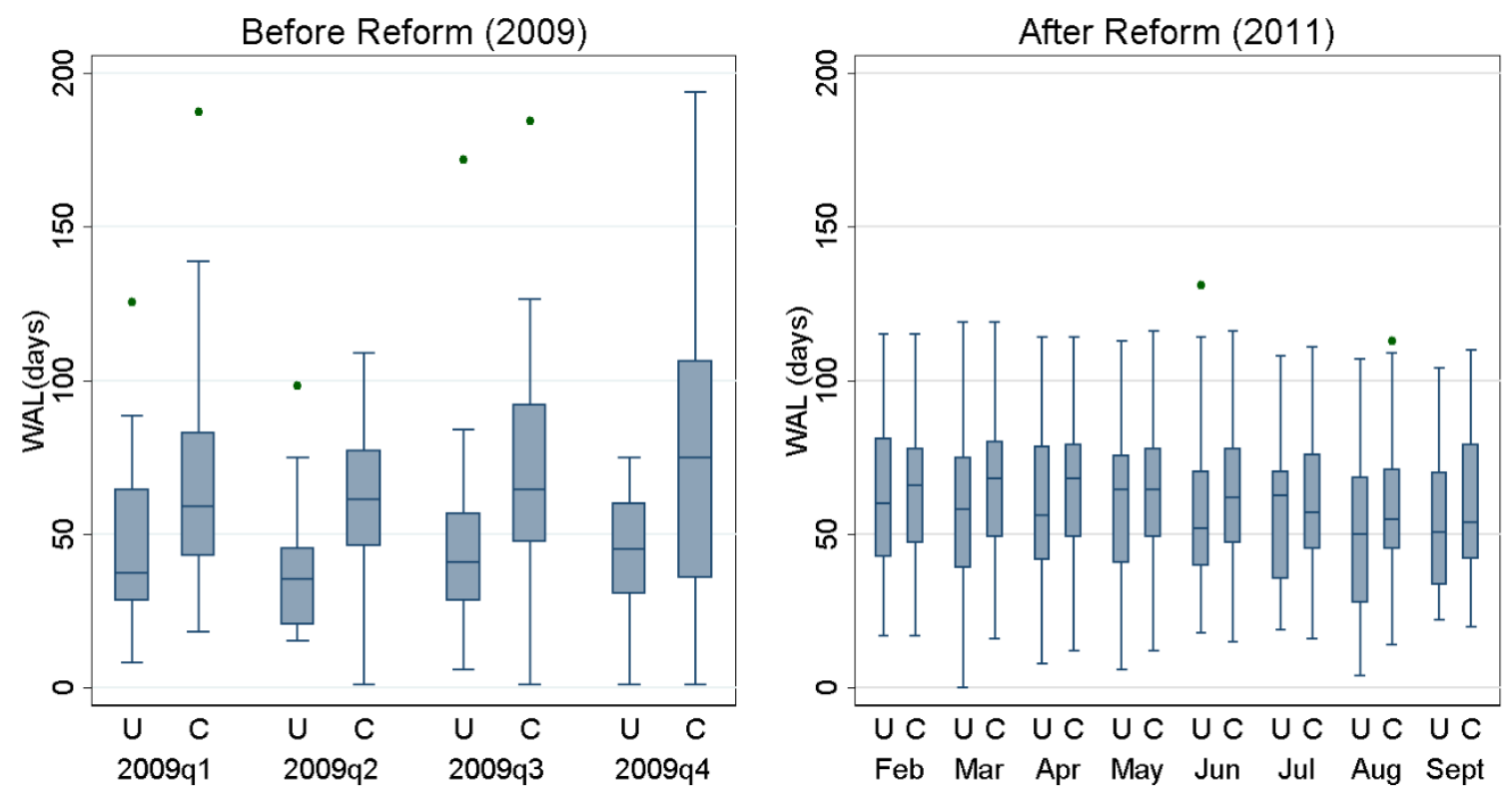

Figure 7: Distribution of Weighted Average Life (WAL) Before and After the 2010 Reform

This figure shows box-and-whisker plots of WAL $\mathrm{ft}_{\mathrm{ft}}$ across funds in each quarter of the before-reform period (January 2009-December 2009), and in each month of a subsample (February 2011- September 2011) of the after-reform period. $\mathrm{WAL}_{\mathrm{ft}}$ is the weighted average life calculated as the dollar-weighted average maturity of a fund's portfolio holdings without regard to interest rate reset dates. Constrained funds are funds that held less than $30 \%$ weekly liquidity before the reform in 2009Q4. Unconstrained funds are the funds that held more than or equal to $30 \%$ weekly liquidity before the reform in 2009Q4. The rectangles show the interquartile range (IQR), which represents the 25th to 75th percentiles, and the horizontal line in the middle of the rectangles is the median. The whiskers below and above the rectangles indicate the lowest and highest WAL values in the data, respectively, that are not outliers. Outliers are any WAL values below Q1 $-1.5 *$ IQR or above Q3 + $1.5 *$ IQR.. Observations falling outside this range are outliers, denoted with a dot (source: N-Q, N-CSR, N-CSRS and N-MFP forms data, authors' own calculations.) 


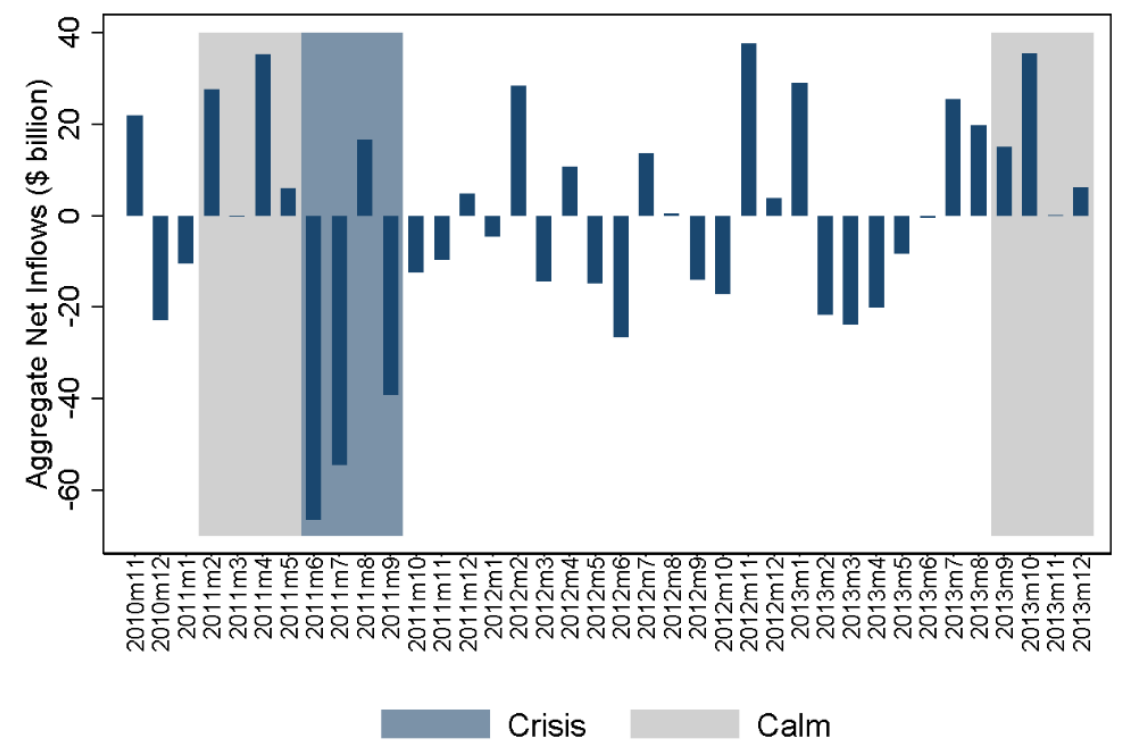

\section{Figure 8: Aggregate Net Inflows of US MMFs}

This figure shows the aggregate net inflows of US MMFs during the sovereign debt crisis (June 2011-September 2011) and the two calm periods used in this paper (February 2011-May 2011 and September 2013-December 2013). Aggregate net inflows is the sum of MMF net inflows (in \$) for each month. Net inflows in dollars are calculated as the difference between fund-level subscriptions and redemptions (source: N-MFP form data, authors' own calculations). 
Table 1. Portfolio Characteristics Before and After the 2010 Reform

\begin{tabular}{|c|c|c|c|c|c|c|c|c|c|}
\hline \multirow[b]{3}{*}{ Mean } & \multicolumn{3}{|c|}{ Constrained Funds (C) } & \multicolumn{3}{|c|}{ Unconstrained Funds (U) } & \multicolumn{3}{|c|}{ "C-U" } \\
\hline & BR & AR & Diff & BR & AR & Diff & BR & $\mathbf{A R}$ & Diff \\
\hline & (1) & (2) & (3) & (4) & (5) & (6) & (7) & (8) & (9) \\
\hline $\mathrm{WLiq}_{\mathrm{ft}} \%$ & $16.51 * * *$ & $41.81 * * *$ & $25.31 * * *$ & $40.11 * * *$ & $44.10 * * *$ & $3.990 * *$ & $-23.60 * * *$ & -2.283 & $21.32 * * *$ \\
\hline $\operatorname{DLiq}_{\mathrm{ft}} \%$ & $10.48 * * *$ & $24.60 * * *$ & $14.11 * * *$ & $24.91 * * *$ & $28.32 * * *$ & 3.415 & $-14.43 * * *$ & -3.730 & $10.70 * * *$ \\
\hline Treasury $_{\mathrm{ft}} \%$ & $1.975 * * *$ & $4.791 * * *$ & $2.82 * * *$ & $3.503 * * *$ & $3.746^{* * *}$ & 0.243 & $-1.528^{*}$ & 1.046 & $2.574 *$ \\
\hline AgcyLiq $_{\mathrm{ft}} \%$ & $2.751 * * *$ & $2.662 * * *$ & -0.0895 & $12.11 * * *$ & $5.314 * * *$ & $-6.792 * * *$ & $-9.355 * * *$ & $-2.652 * * *$ & $6.703 * * *$ \\
\hline NonGovLiq $\mathrm{ft}_{\mathrm{ft}} \%$ & $11.80 * * *$ & $34.21 * * *$ & $22.41 * * *$ & $24.34 * * *$ & $34.26 * * *$ & $9.927 * * *$ & $-12.54 * * *$ & -0.0518 & $12.48 * * *$ \\
\hline $\mathrm{WAL}_{\mathrm{ft}}$ (days) & $85.66 * * *$ & $65.50 * * *$ & $-20.16 * *$ & $48.90 * * *$ & $61.55^{* * *}$ & $12.65^{* *}$ & $36.76 * * *$ & 3.948 & $-32.82 * * *$ \\
\hline $\mathrm{OA}_{0-3 \mathrm{~m}, \mathrm{ft}} \%$ & $66.20 * * *$ & $87.05 * * *$ & $20.86 * * *$ & $81.73 * * *$ & $87.99 * * *$ & $6.260 * * *$ & $-15.53 * * *$ & -0.938 & $14.60 * * *$ \\
\hline $\mathrm{OA}_{9-13 \mathrm{~m}, \mathrm{ft}} \%$ & $9.577 * * *$ & $2.337 * * *$ & $-7.239 * * *$ & $8.906^{* *}$ & $3.050 * * *$ & -5.856 & 0.671 & $-0.712 *$ & -1.383 \\
\hline $\operatorname{Spread}_{0-3 \mathrm{~m}, \mathrm{ft}}(\mathrm{bp})$ & $41.52 * * *$ & $20.84 * * *$ & $-20.68 * * *$ & $37.43 * * *$ & $20.75 * * *$ & $-16.68 * * *$ & 4.092 & 0.0852 & -4.007 \\
\hline Spread $_{9-13 m, f t}(b p)$ & $52.00 * * *$ & $87.92 * * *$ & $35.93 *$ & $40.91 * * *$ & $72.89 * * *$ & 31.98 & 11.08 & 15.03 & 3.949 \\
\hline PortRisk $_{\mathrm{ft}}(\mathrm{bp})$ & $51.75^{* * *}$ & $27.39 * * *$ & $-24.36 * * *$ & $47.01 * * *$ & $26.64 * * *$ & $-20.36 * * *$ & 4.742 & 0.746 & -3.997 \\
\hline $\operatorname{NetAssets}_{\mathrm{ft}}(\$ \mathrm{bn})$ & $5.347 * * *$ & $5.170 * * *$ & -0.177 & $3.917 * * *$ & $4.700 * * *$ & 0.783 & 1.430 & 0.470 & -0.960 \\
\hline No of funds & 65 & 65 & 65 & 35 & 35 & 35 & 100 & 100 & 100 \\
\hline \multicolumn{10}{|c|}{ 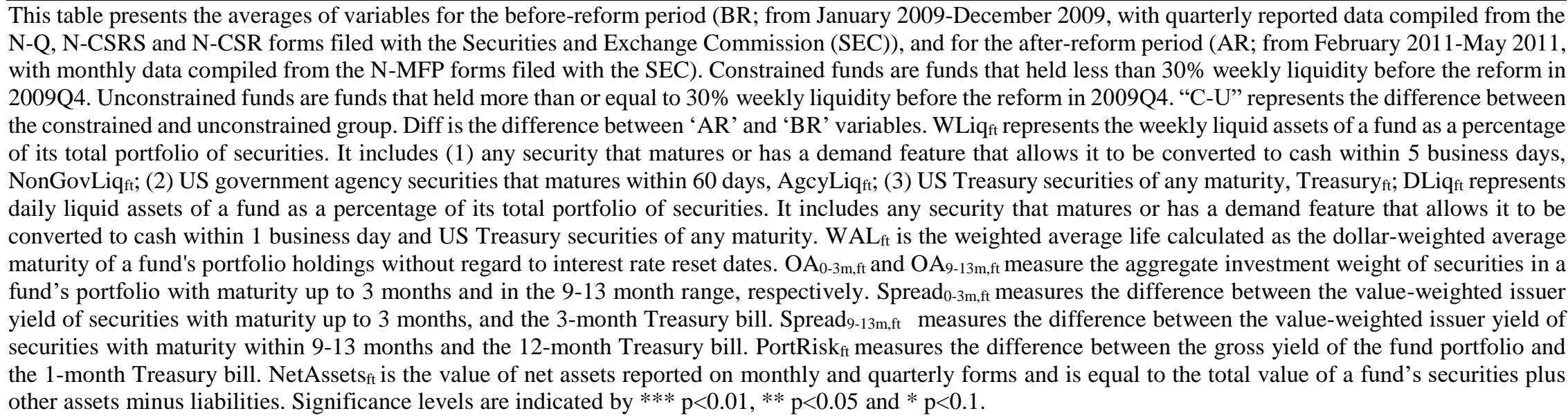 } \\
\hline
\end{tabular}


Table 2. Quintile Differences in Weekly and Daily Liquidity Before and After the Reform

\begin{tabular}{|c|c|c|c|c|c|c|c|c|c|}
\hline \multirow[b]{3}{*}{ Mean of $\mathrm{WLiq}_{\mathrm{ft}}$ by quintile } & \multicolumn{3}{|c|}{ Constrained Funds (C) } & \multicolumn{3}{|c|}{ Unconstrained Funds (U) } & \multicolumn{3}{|l|}{ “C-U” } \\
\hline & Before & After & Diff & Before & After & Diff & Before & After & Diff \\
\hline & (1) & $(2)$ & $(3)$ & (4) & $(5)$ & $(6)$ & (7) & $(8)$ & $(9)$ \\
\hline Quintile 1 & $5.237 * * *$ & $49.49 * * *$ & $44.25 * * *$ & $32.04 * * *$ & $51.13 * * *$ & $19.09 * * *$ & $-26.80 * * *$ & -1.642 & $25.16^{* * *}$ \\
\hline Quintile 2 & $12.05^{* * *}$ & $39.75^{* * *}$ & $27.70 * * *$ & $36.41 * * *$ & $54.89 * * *$ & $18.49 * * *$ & $-24.35 * * *$ & $-15.14 * * *$ & $9.213 * * *$ \\
\hline Quintile 3 & $17.94 * * *$ & $36.01 * * *$ & $18.07 * * *$ & $40.39 * * *$ & $52.69 * * *$ & $12.30 * * *$ & $-22.45^{* * *}$ & $-16.68 * * *$ & 5.770 \\
\hline Quintile 4 & $21.70 * * *$ & $54.94 * * *$ & $33.24 * * *$ & $41.87 * * *$ & $50.18 * * *$ & $8.310 * * *$ & $-20.17 * * *$ & 4.761 & $24.93 * * *$ \\
\hline Quintile 5 & $24.25^{* * *}$ & $48.31 * * *$ & $24.06 * * *$ & $59.85 * * *$ & $54.85^{* * *}$ & -5.002 & $-35.60 * * *$ & -6.539 & $29.06 * * *$ \\
\hline \multirow[t]{3}{*}{ No of funds } & 65 & 65 & 65 & 35 & 35 & 35 & 100 & 100 & 100 \\
\hline & \multicolumn{3}{|c|}{ Constrained Funds (C) } & \multicolumn{3}{|c|}{ Unconstrained Funds (U) } & \multicolumn{3}{|l|}{ "C-U" } \\
\hline & Before & After & Diff & Before & After & Diff & Before & After & Diff \\
\hline Mean of DLiq $\mathrm{ft}_{\mathrm{ft}}$ by quintile & (1) & $(2)$ & $(3)$ & (4) & $(5)$ & (6) & $(7)$ & $(8)$ & $(9)$ \\
\hline Quintile 1 & $3.188 * * *$ & $27.47 * * *$ & $24.28 * * *$ & $20.73 * * *$ & $36.28 * * *$ & $15.55 * * *$ & $-17.55 * * *$ & $-8.808 * *$ & $8.737 *$ \\
\hline Quintile 2 & $6.635^{* * *}$ & $19.39 * * *$ & $12.75 * * *$ & $24.93 * * *$ & $34.99 * * *$ & $10.06^{* *}$ & $-18.30 * * *$ & $-15.60 * * *$ & 2.698 \\
\hline Quintile 3 & $11.60 * * *$ & $18.98 * * *$ & $7.387 * * *$ & $28.55 * * *$ & $36.52 * * *$ & 7.973 & $-16.95 * * *$ & $-17.54 * * *$ & -0.586 \\
\hline Quintile 4 & $15.89 * * *$ & $35.77 * * *$ & $19.88 * * *$ & $28.74 * * *$ & $34.03 * * *$ & 5.291 & $-12.85 * * *$ & 1.745 & $14.59 * *$ \\
\hline Quintile 5 & $16.92 * * *$ & $36.64 * * *$ & $19.72 * * *$ & $37.05 * * *$ & $29.27 * * *$ & -7.779 & $-20.13 * * *$ & 7.366 & $27.50 * * *$ \\
\hline No of funds & 65 & 65 & 65 & 35 & 35 & 35 & 100 & 100 & 100 \\
\hline
\end{tabular}


Table 3. MMF Liquidity in Calm and Crisis Periods (After the Reform)

\begin{tabular}{|c|c|c|c|c|c|c|c|c|c|}
\hline \multirow[b]{3}{*}{ Mean } & \multicolumn{3}{|c|}{ Constrained Funds (C) } & \multicolumn{3}{|c|}{ Unconstrained Funds (U) } & \multicolumn{3}{|c|}{ "C-U" } \\
\hline & Calm & Crisis & Diff & Calm & Crisis & Diff & Calm & Crisis & Diff \\
\hline & (1) & $(2)$ & (3) & (4) & (5) & $(6)$ & (7) & (8) & (9) \\
\hline $\mathrm{WLiq}_{\mathrm{ft}}(\%)$ & $41.81 * * *$ & $45.68 * * *$ & $3.863^{*}$ & $44.10 * * *$ & $52.55 * * *$ & $8.451 * * *$ & -2.283 & $-6.871 * *$ & -4.588 \\
\hline $\operatorname{DLiq}_{\mathrm{ft}}(\%)$ & $24.60 * * *$ & $27.15^{* * *}$ & 2.553 & $28.32 * * *$ & $33.29 * * *$ & 4.965 & -3.730 & $-6.141 * *$ & -2.411 \\
\hline $\mathrm{WAL}_{\mathrm{ft}}$ (days) & $65.52 * * *$ & $58.67 * * *$ & $-6.850^{*}$ & $61.60 * * *$ & $55.47 * * *$ & -6.127 & 3.923 & 3.200 & -0.723 \\
\hline No of funds & 65 & 65 & 65 & 35 & 35 & 35 & 100 & 100 & 100 \\
\hline
\end{tabular}

This table presents the averages of the liquidity and weighted average life variables, which are divided into the calm period (February 2011-May 2011) and crisis period (June 2011-September 2011). Constrained funds are funds that held less than 30\% weekly liquidity before the reform in 2009Q4. Unconstrained funds are funds that held more than or equal to 30\% weekly liquidity before the reform in 2009Q4. "C-U" represents the difference between the constrained and unconstrained group. Diff is the difference between crisis and calm periods. WLiqft represents the weekly liquid assets of a fund as a percentage of its total portfolio of securities. It includes (1) any security that matures or has a demand feature that allows it to be converted to cash within 5 business days. DLiqft represents the daily liquid assets of a fund as a percentage of its total portfolio of securities. It includes any security that matures or has a demand feature that allows it to be converted to cash within 1 business day and US Treasury securities of any maturity. WAL $\mathrm{Wt}_{\mathrm{ft}}$ is the weighted average life calculated as the dollar-weighted average maturity of a fund's portfolio holdings without regard to interest rate reset dates. Significance levels are indicated by $* * * p<0.01, * * p<0.05$ and $* p<0.1$. 
Table 4. Impact of the Reform on Counterfactual Crisis-Level Excess Liquidity

\begin{tabular}{|c|c|c|c|c|c|c|}
\hline \multirow[t]{2}{*}{ DepVar: } & \multicolumn{3}{|c|}{$\begin{array}{c}\text { Panel A: Weekly Excess Liquidity } \\
\text { ExWLiqft }\end{array}$} & \multicolumn{3}{|c|}{$\begin{array}{c}\text { Panel B: Daily Excess Liquidity } \\
\text { ExDLiq }_{\mathrm{ft}}\end{array}$} \\
\hline & $\begin{array}{l}\text { “C” } \\
\text { (1) }\end{array}$ & $\begin{array}{l}\text { “U” } \\
(2)\end{array}$ & $\begin{array}{c}\text { "C+U" } \\
(3)\end{array}$ & $\begin{array}{l}\text { “C" } \\
(4)\end{array}$ & $\begin{array}{l}\text { “U” } \\
(5)\end{array}$ & $\begin{array}{c}\text { “C+U” } \\
(6)\end{array}$ \\
\hline Reform $_{t}$ & $\begin{array}{c}29.026 * * * \\
(4.234)\end{array}$ & $\begin{array}{c}10.85 \\
(9.849)\end{array}$ & $\begin{array}{c}10.89 * * \\
(4.802)\end{array}$ & $\begin{array}{c}18.157 * * * \\
(3.185)\end{array}$ & $\begin{array}{c}5.845 \\
(8.416)\end{array}$ & $\begin{array}{c}7.101 \\
(5.190)\end{array}$ \\
\hline $\operatorname{Reform}_{\mathrm{t}} * \operatorname{Con}_{\mathrm{f}}$ & & & $\begin{array}{c}15.94 * * * \\
(3.704)\end{array}$ & & & $\begin{array}{l}9.547 * \\
(4.915)\end{array}$ \\
\hline $\mathrm{Con}_{\mathrm{f}}$ & & & $\begin{array}{c}-21.01 * * * \\
(3.401)\end{array}$ & & & $\begin{array}{c}-13.43 * * * \\
(4.192)\end{array}$ \\
\hline ExpOutflowsft-1 & $\begin{array}{c}0.172 \\
(0.354)\end{array}$ & $\begin{array}{l}-0.119 \\
(0.410)\end{array}$ & $\begin{array}{c}0.149 \\
(0.186)\end{array}$ & $\begin{array}{l}-0.169 \\
(0.262)\end{array}$ & $\begin{array}{l}-0.0501 \\
(0.335)\end{array}$ & $\begin{array}{l}0.0601 \\
(0.218)\end{array}$ \\
\hline PortRisk $_{\mathrm{ft}-1}$ & $\begin{array}{l}-0.052 \\
(0.077)\end{array}$ & $\begin{array}{l}-0.0826 \\
(0.143)\end{array}$ & $\begin{array}{l}-0.0764^{*} \\
(0.0417)\end{array}$ & $\begin{array}{c}0.027 \\
(0.058)\end{array}$ & $\begin{array}{l}-0.0811 \\
(0.126)\end{array}$ & $\begin{array}{l}-0.0365 \\
(0.0491)\end{array}$ \\
\hline FlowVol $_{\mathrm{ft}-1}$ & $\begin{array}{l}0.226^{*} \\
(0.120)\end{array}$ & $\begin{array}{l}0.106 \\
(0.184)\end{array}$ & $\begin{array}{c}0.115 \\
(0.0829)\end{array}$ & $\begin{array}{c}0.135 \\
(0.116)\end{array}$ & $\begin{array}{c}0.102 \\
(0.194)\end{array}$ & $\begin{array}{c}0.0569 \\
(0.0639)\end{array}$ \\
\hline ExpInflows $_{\mathrm{ft}-1}$ & $\begin{array}{l}-0.242 \\
(0.504)\end{array}$ & $\begin{array}{c}0.216 \\
(0.872)\end{array}$ & $\begin{array}{l}-0.193 \\
(0.377)\end{array}$ & $\begin{array}{l}-0.221 \\
(0.373)\end{array}$ & $\begin{array}{c}0.352 \\
(0.791)\end{array}$ & $\begin{array}{l}-0.0570 \\
(0.358)\end{array}$ \\
\hline $\operatorname{Size}_{\mathrm{ft}-1}$ & & & $\begin{array}{c}-1.739 * * \\
(0.688)\end{array}$ & & & $\begin{array}{l}-0.637 \\
(0.773)\end{array}$ \\
\hline Constant & $\begin{array}{l}15.108 * * * \\
(5.648)\end{array}$ & $\begin{array}{c}39.71 * * * \\
(11.90)\end{array}$ & $\begin{array}{c}75.51 * * * \\
(15.83)\end{array}$ & $\begin{array}{l}5.880 \\
(4.190)\end{array}$ & $\begin{array}{r}24.08 * * \\
(10.30)\end{array}$ & $\begin{array}{c}36.13 * * \\
(17.25)\end{array}$ \\
\hline Fund Fixed Effects & $\mathrm{Y}$ & $\mathrm{Y}$ & $\mathrm{N}$ & $\mathrm{Y}$ & $\mathrm{Y}$ & $\mathrm{N}$ \\
\hline Time Fixed Effects & $\mathrm{Y}$ & $\mathrm{Y}$ & $\mathrm{Y}$ & $\mathrm{Y}$ & $\mathrm{Y}$ & $\mathrm{Y}$ \\
\hline Adjusted $\mathrm{R}^{2}$ & 0.630 & 0.201 & 0.509 & 0.455 & 0.0869 & 0.331 \\
\hline Observations & 337 & 191 & 516 & 337 & 191 & 516 \\
\hline $\begin{array}{l}\text { Wald Test: } \\
\text { Con }_{\mathrm{f}}\left(1+\text { Reform }_{\mathrm{t}}\right)\end{array}$ & & & $-5.07 * *$ & & & -3.88 \\
\hline
\end{tabular}

This table presents the results of panel regressions that measure the impact of the reform on counter-factual crisis level excess liquidity. The sample period includes the before-reform period (January 2009-December 2009) and the afterreform crisis period (June 2011-September 2011). In Panel A, the dependent variable is excess weekly liquidity, ExWLiq $_{\mathrm{ft}}$, which is calculated as lagged weekly liquidity, WLiq $\mathrm{ft}_{-1}$ in excess of the average net outflows a fund experiences during the sovereign debt crisis, $\overline{\text { Outflows }} \mathrm{f}_{\mathrm{f}, \mathrm{criss}}$. In Panel $\mathrm{B}$, the dependent variable is excess daily liquidity, $\mathrm{ExDLiq}_{\mathrm{ft}}$, which is calculated as lagged daily liquidity, DLiq $\mathrm{ft}_{\mathrm{ft}-1}$ in excess of the average net outflows a fund experienced

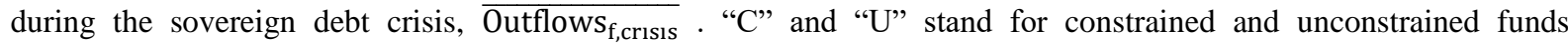
respectively. ' $\mathrm{C}+\mathrm{U}$ ' columns include both constrained and unconstrained funds. $\mathrm{Con}_{\mathrm{f}}$ is a dummy variable which takes a value of one for constrained funds and zero for unconstrained funds. Reform $t$ is a dummy variable which takes a value of 1 for the after-reform crisis period (June 2011-September 2011) and zero for the before-reform period (January 2009December 2009). The ExpOutflows $\mathrm{ft}_{\mathrm{ft}}$ are the forecast net outflows and ExpInflows $\mathrm{ft}$ are the forecast net inflows. FlowVol $_{\mathrm{ft}}$ is the recursive standard deviation of the NetInflows $\mathrm{s}_{\mathrm{ft}}$ of a fund. NetInflows $\mathrm{ft}_{\mathrm{ft}}$ is the difference between the monthly fund-level subscriptions and redemptions scaled by lagged net assets. PortRisk $\mathrm{ft}_{\mathrm{ft}}$ measures the difference between the gross yield of the fund portfolio and the 1-month Treasury bill. Size $\mathrm{ft}_{\mathrm{ft}}$ is the log of the net assets of a fund. All variables are winsorised at the $1^{\text {st }}$ and $99^{\text {th }}$ percentiles. In all regressions, we calculate bootstrapped standard errors which are clustered by funds (see Appendix A.1 for detailed definitions of all the variables). Significance levels are indicated by $* * * \mathrm{p}<0.01, * * \mathrm{p}<0.05$ and $* \mathrm{p}<0.1$. 
Table 5. Distribution of Counterfactual Crisis-Level Excess Liquidity

\begin{tabular}{|c|c|c|c|c|c|c|c|c|}
\hline \multicolumn{9}{|c|}{ Panel A: Constrained Funds } \\
\hline & \multicolumn{2}{|c|}{ ExWLiq } & \multicolumn{2}{|c|}{ ExDLiq $_{\mathrm{ft}}$} & \multicolumn{2}{|c|}{ ExWLiq_WC } & \multicolumn{2}{|c|}{ ExDLiq_WC ft } \\
\hline & BR & $\mathbf{A R}$ & $\mathbf{B R}$ & $\mathbf{A R}$ & $\mathbf{B R}$ & $\mathbf{A R}$ & $\mathbf{B R}$ & $\mathbf{A R}$ \\
\hline & (1) & (2) & (3) & (4) & (5) & (6) & (7) & (8) \\
\hline Mean & 15.75 & 42.54 & 9.01 & 24.52 & 12.26 & 37.60 & 5.59 & 19.57 \\
\hline SD & 11.14 & 14.90 & 8.10 & 14.43 & 11.92 & 15.75 & 9.16 & 14.74 \\
\hline p1 & -5.20 & 20.58 & -9.36 & 4.04 & -11.86 & 6.95 & -13.93 & -7.92 \\
\hline p5 & -1.12 & 25.66 & -1.25 & 8.74 & -9.02 & 17.43 & -7.98 & 2.28 \\
\hline p10 & 0.73 & 28.76 & -0.19 & 10.05 & -3.34 & 21.39 & -4.83 & 5.84 \\
\hline p25 & 8.04 & 32.00 & 2.80 & 13.92 & 2.98 & 27.37 & -1.16 & 9.76 \\
\hline p50 & 16.64 & 37.67 & 8.39 & 21.09 & 12.45 & 33.47 & 5.08 & 15.51 \\
\hline p75 & 22.96 & 48.95 & 13.93 & 32.08 & 19.83 & 45.46 & 11.55 & 26.55 \\
\hline p90 & 28.68 & 63.92 & 20.65 & 47.20 & 26.74 & 60.09 & 17.56 & 40.51 \\
\hline $\mathrm{N}$ & 180 & 255 & 175 & 255 & 180 & 255 & 175 & 255 \\
\hline$<$ Minimum Requirement & - & $16^{\text {th }}$ & - & $10^{\text {th }}$ & - & $36^{\text {th }}$ & - & $27^{\text {th }}$ \\
\hline Liquidity Shortage & $8^{\text {th }}$ & $0^{\text {th }}$ & $12^{\text {th }}$ & $0^{\text {th }}$ & $18^{\text {th }}$ & $0^{\text {th }}$ & $29^{\text {th }}$ & $3^{\text {rd }}$ \\
\hline \multicolumn{9}{|c|}{ Panel B: Unconstrained Funds } \\
\hline & \multicolumn{2}{|c|}{ ExWLiq } & \multicolumn{2}{|c|}{ ExDLiqft $_{\mathrm{f}}$} & \multicolumn{2}{|c|}{ ExWLiq_WC } & \multicolumn{2}{|c|}{ ExDLiq_WC } \\
\hline & BR & $\mathbf{A R}$ & $\mathbf{B R}$ & $\mathbf{A R}$ & $\mathbf{B R}$ & $\mathbf{A R}$ & $\mathbf{B R}$ & AR \\
\hline & (1) & (2) & (3) & (4) & (5) & (6) & (7) & (8) \\
\hline Mean & 37.53 & 47.03 & 23.56 & 28.27 & 33.84 & 41.97 & 19.85 & 23.26 \\
\hline SD & 16.11 & 14.82 & 15.06 & 14.26 & 16.39 & 16.22 & 14.82 & 15.70 \\
\hline p1 & -5.20 & 22.89 & -9.36 & 2.91 & -11.86 & 11.23 & -13.93 & -9.15 \\
\hline p5 & 15.26 & 28.43 & 5.04 & 10.45 & 13.09 & 18.91 & -1.13 & -0.98 \\
\hline p10 & 21.19 & 31.90 & 9.56 & 12.67 & 15.47 & 24.08 & 3.21 & 6.47 \\
\hline p25 & 29.83 & 36.31 & 13.85 & 18.22 & 22.90 & 30.97 & 9.56 & 11.68 \\
\hline p50 & 36.69 & 43.07 & 21.78 & 23.61 & 32.90 & 39.21 & 18.76 & 20.20 \\
\hline P75 & 44.30 & 52.87 & 30.17 & 37.28 & 42.78 & 49.34 & 28.07 & 33.96 \\
\hline p90 & 51.74 & 74.22 & 38.70 & 49.27 & 51.39 & 69.63 & 34.81 & 46.90 \\
\hline $\mathrm{N}$ & 91 & 140 & 91 & 140 & 91 & 140 & 91 & 140 \\
\hline$<$ Minimum Requirement & - & $8^{\text {th }}$ & - & $5^{\text {th }}$ & - & $24^{\text {th }}$ & - & $18^{\text {th }}$ \\
\hline Liquidity Shortage & $2^{\text {nd }}$ & $0^{\text {th }}$ & $3^{\text {rd }}$ & $0^{\text {th }}$ & $2^{\text {nd }}$ & $0^{\text {th }}$ & $6^{\text {th }}$ & $5^{\text {th }}$ \\
\hline
\end{tabular}

This table presents the distribution of the counterfactual excess liquidity variables for the before-reform period (BR; from January 2009 to December 2009 with quarterly reported data compiled from the N-Q, N-CSRS and N-CSR forms filed with the Securities and Exchange Commission (SEC)) and for the after-reform crisis period (AR; from June 2011 to September 2011 with monthly data compiled from the N-MFP form filed with the SEC). Constrained funds are funds that held less than 30\% weekly liquidity before the reform in 2009Q4. Unconstrained funds are funds that held more than or equal to $30 \%$ weekly liquidity before the reform in 2009Q4. Excess weekly (daily) liquidity, ExWLiq $_{\mathrm{ft}}\left(\right.$ ExDLiq $_{\mathrm{ft}}$ ), is calculated as lagged weekly (daily) liquidity, $\mathrm{WLiq}_{\mathrm{ft}-1}\left(\mathrm{DLiq}_{\mathrm{ft}-1}\right)$, in excess of the average outflows a fund experienced during the sovereign debt crisis, $\overline{\text { Outflows }_{\mathrm{f}, \mathrm{crisss}}}$. ExWLiq_WC $\mathrm{WC}_{\mathrm{ft}}\left(\right.$ ExDLiq_WC $\left._{\mathrm{ft}}\right)$ is the worst-case excess weekly (daily) liquidity calculated as the difference between lagged weekly (daily) liquidity, WLiq $\mathrm{ft}_{\mathrm{f}}$ ${ }_{1}$ (DLiq $_{\mathrm{ft}-1}$ ), and the highest level of net outflows, Outflows $\mathrm{f}_{\mathrm{f} \text {,risis }}$ for the sovereign debt crisis (June 2011-September 2011). '<Minimum Requirement' is the fund-month percentile rank at which funds do not meet the minimum liquidity requirement mandated by the SEC 2010 amendments after servicing the redemptions. 'Liquidity Shortage' is the percentile rank at which the funds no longer have liquidity to meet Outflowsf,crisis. 
Table 6. Impact of "Know Your Investor" Requirement

\begin{tabular}{|c|c|c|c|c|c|c|}
\hline \multirow[t]{2}{*}{ DepVar: } & \multicolumn{3}{|c|}{$\begin{array}{c}\text { Panel A: Weekly Liquidity } \\
\text { WLiqft }\end{array}$} & \multicolumn{3}{|c|}{$\begin{array}{c}\text { Panel B: Daily Liquidity } \\
\text { DLiqft }_{\mathrm{ft}}\end{array}$} \\
\hline & (1) & $(2)$ & (3) & $(4)$ & (5) & (6) \\
\hline ExpOutflows $_{\mathrm{ft}-1} *$ Crisis $_{\mathrm{t}}$ & $\begin{array}{l}2.691 * * \\
(1.187)\end{array}$ & $\begin{array}{l}2.918 * * * \\
(1.123)\end{array}$ & $\begin{array}{l}2.968 * * * \\
(1.141)\end{array}$ & $\begin{array}{l}2.610 * * \\
(1.284)\end{array}$ & $\begin{array}{l}2.204 * * \\
(1.106)\end{array}$ & $\begin{array}{c}2.654 * * * \\
(1.030)\end{array}$ \\
\hline ExpOutflows $_{\mathrm{ft}-1}$ & $\begin{array}{c}0.197 \\
(0.180)\end{array}$ & $\begin{array}{c}0.085 \\
(0.188)\end{array}$ & $\begin{array}{c}0.065 \\
(0.166)\end{array}$ & $\begin{array}{l}-0.262 \\
(0.186)\end{array}$ & $\begin{array}{l}-0.266 \\
(0.170)\end{array}$ & $\begin{array}{l}-0.277^{*} \\
(0.162)\end{array}$ \\
\hline PortRisk $_{\mathrm{ft}-1} *$ Crisis $_{\mathrm{t}}$ & $\begin{array}{c}0.295 \\
(0.234)\end{array}$ & $\begin{array}{c}0.358 \\
(0.239)\end{array}$ & $\begin{array}{l}0.477 * * \\
(0.223)\end{array}$ & $\begin{array}{l}-0.050 \\
(0.109)\end{array}$ & $\begin{array}{l}0.294 * * * \\
(0.111)\end{array}$ & $\begin{array}{l}0.376^{* * *} \\
(0.107)\end{array}$ \\
\hline PortRisk $_{\mathrm{ft}-1}$ & $\begin{array}{c}-1.203 * * * \\
(0.337)\end{array}$ & $\begin{array}{l}-1.237 * * * \\
(0.332)\end{array}$ & $\begin{array}{l}-1.368 * * * \\
(0.258)\end{array}$ & $\begin{array}{l}-0.235 \\
(0.154)\end{array}$ & $\begin{array}{l}-0.578 * * * \\
(0.164)\end{array}$ & $\begin{array}{l}-0.734 * * * \\
(0.125)\end{array}$ \\
\hline FlowVol $_{\mathrm{ft}-1} *$ Crisis $_{\mathrm{t}}$ & $\begin{array}{l}-0.062 \\
(0.221)\end{array}$ & $\begin{array}{l}-0.009 \\
(0.218)\end{array}$ & $\begin{array}{c}0.004 \\
(0.205)\end{array}$ & $\begin{array}{c}0.045 \\
(0.154)\end{array}$ & $\begin{array}{c}0.154 \\
(0.140)\end{array}$ & $\begin{array}{c}0.181 \\
(0.135)\end{array}$ \\
\hline Flow Volft-1 & $\begin{array}{c}0.167 \\
(0.148)\end{array}$ & $\begin{array}{c}0.166 \\
(0.144)\end{array}$ & $\begin{array}{l}0.195 * \\
(0.114)\end{array}$ & $\begin{array}{c}0.023 \\
(0.233)\end{array}$ & $\begin{array}{c}0.040 \\
(0.146)\end{array}$ & $\begin{array}{l}-0.002 \\
(0.098)\end{array}$ \\
\hline ExpInflows $_{\mathrm{ft}-1} *$ Crisis $_{\mathrm{t}}$ & $\begin{array}{c}0.229 \\
(0.594)\end{array}$ & $\begin{array}{c}0.109 \\
(0.615)\end{array}$ & $\begin{array}{c}0.214 \\
(0.595)\end{array}$ & $\begin{array}{c}0.523 \\
(0.731)\end{array}$ & $\begin{array}{c}0.244 \\
(0.473)\end{array}$ & $\begin{array}{c}0.605 \\
(0.421)\end{array}$ \\
\hline ExpInflows $_{\mathrm{ft}-1}$ & $\begin{array}{c}0.391 \\
(0.410)\end{array}$ & $\begin{array}{c}0.453 \\
(0.431)\end{array}$ & $\begin{array}{c}0.502 \\
(0.387)\end{array}$ & $\begin{array}{l}-0.538 \\
(0.611)\end{array}$ & $\begin{array}{l}-0.048 \\
(0.327)\end{array}$ & $\begin{array}{l}-0.187 \\
(0.315)\end{array}$ \\
\hline InstShare $_{\mathrm{ft}-1}$ & $\begin{array}{l}-0.036 \\
(0.139)\end{array}$ & $\begin{array}{l}-0.032 \\
(0.144)\end{array}$ & $\begin{array}{c}0.002 \\
(0.014)\end{array}$ & $\begin{array}{l}-0.104 \\
(0.147)\end{array}$ & $\begin{array}{c}-0.072 \\
(0.109)\end{array}$ & $\begin{array}{c}0.003 \\
(0.011)\end{array}$ \\
\hline Crisis $_{t}$ & $\begin{array}{c}0.544 \\
(2.782)\end{array}$ & $\begin{array}{c}2.250 \\
(3.441)\end{array}$ & $\begin{array}{c}8.746 * * \\
(4.083)\end{array}$ & $\begin{array}{c}-0.771 \\
(1.745)\end{array}$ & $\begin{array}{c}13.578 * \\
(7.171)\end{array}$ & $\begin{array}{c}15.812 * * * \\
(5.427)\end{array}$ \\
\hline $\operatorname{Con}_{\mathrm{f}} *$ Crisis $_{\mathrm{t}}$ & & & $\begin{array}{c}-5.223 * * \\
(2.375)\end{array}$ & & & $\begin{array}{l}-2.430 \\
(1.593)\end{array}$ \\
\hline $\operatorname{Con}_{\mathrm{f}}$ & & & $\begin{array}{c}-8.152 * * * \\
(2.243)\end{array}$ & & & $\begin{array}{c}-3.081 * * \\
(1.295)\end{array}$ \\
\hline $\operatorname{Size}_{\mathrm{ft}-1}$ & & & $\begin{array}{c}-0.531 \\
(0.361)\end{array}$ & & & $\begin{array}{l}-0.004 \\
(0.218)\end{array}$ \\
\hline Constant & $\begin{array}{c}48.000 * * * \\
(10.918)\end{array}$ & $\begin{array}{c}45.059 * * * \\
(11.122)\end{array}$ & $\begin{array}{c}60.611 * * * \\
(8.070)\end{array}$ & $\begin{array}{c}27.035 * * \\
(10.961)\end{array}$ & $\begin{array}{c}17.815 * * \\
(8.084)\end{array}$ & $\begin{array}{c}16.432 * * * \\
(4.558)\end{array}$ \\
\hline Fund Fixed Effects & $\mathrm{Y}$ & $\mathrm{Y}$ & $\mathrm{N}$ & Y & $\mathrm{Y}$ & $\mathrm{N}$ \\
\hline Time Fixed Effects & $\mathrm{N}$ & $\mathrm{Y}$ & $\mathrm{Y}$ & $\mathrm{N}$ & $\mathrm{Y}$ & $\mathrm{Y}$ \\
\hline Adjusted $\mathrm{R}^{2}$ & 0.155 & 0.203 & 0.211 & 0.0104 & 0.546 & 0.545 \\
\hline Observations & 1,195 & 1,195 & 1,195 & 1,195 & 1,195 & 1,195 \\
\hline Wald Tests: & & & & & & \\
\hline ExpOutflows $_{\mathrm{ft}-1}\left(1+\right.$ Crisis $\left._{\mathrm{t}}\right)$ & $2.888 * *$ & $3.003 * * *$ & $3.033 * * *$ & $2.348 * *$ & $1.938 *$ & $2.377 * * *$ \\
\hline PortRisk $_{\mathrm{ft}-1}\left(1+\right.$ Crisis $\left._{\mathrm{t}}\right)$ & $-0.908 * * *$ & $-0.879 * * *$ & $-0.891 * * *$ & $-0.285 * * *$ & $-0.284 * * *$ & $-0.358 * * *$ \\
\hline FlowVol $_{\mathrm{ft}-1}\left(1+\right.$ Crisis $\left._{\mathrm{t}}\right)$ & 0.105 & 0.157 & 0.199 & 0.068 & 0.194 & 0.179 \\
\hline ExpInflows $_{\mathrm{ft}-1}\left(1+\right.$ Crisis $\left._{\mathrm{t}}\right)$ & 0.62 & 0.562 & 0.716 & -0.015 & 0.196 & 0.418 \\
\hline $\operatorname{Con}_{\mathrm{f}}\left(1+\right.$ Crisis $\left._{\mathrm{t}}\right)$ & & & $-13.375 * * *$ & & & $-5.511 * * *$ \\
\hline
\end{tabular}

This table presents the results of panel regressions that test the 'know your investor' requirement. The sample includes the crisis period (June 2011-September 2011) and calm period (September 2013-December 2013). The dependent variable in Panel A is weekly liquidity, WLiq $\mathrm{ft}_{\mathrm{t}}$, which represents the weekly liquid assets of a fund as a percentage of its total portfolio of securities. It includes any security that matures or has a demand feature that allows it to be converted to cash within 5 business days, US government agency securities that mature within 60 days, and US Treasury securities of any maturity. The dependent variable in Panel B is daily liquidity, DLiq $\mathrm{ft}_{\mathrm{t}}$, which represents the daily liquid assets of a fund as a percentage of its total portfolio of securities. It includes any security that matures or has a demand feature that allows it to be converted to cash within 1 business day and US Treasury securities of any maturity. The Crisis $\mathrm{t}_{\mathrm{t}}$ dummy takes a value of one for the crisis period (June 2011-September 2011) and a value of zero for the calm period (September 2013-December 2013). The ExpOutflows are the forecast net outflows. PortRisk $\mathrm{ft}_{\mathrm{ft}}$ 
measures the difference between the gross yield of the fund portfolio and the 1-month Treasury bill. FlowVol $\mathrm{l}_{\mathrm{ft}}$ is the rolling standard deviation of NetInflows $\mathrm{ft}_{\mathrm{ft}}$ of a fund. NetInflows $\mathrm{ft}_{\mathrm{ft}}$ is the difference between the monthly fund-level subscriptions and redemptions scaled by lagged net assets. ExpInflows $\mathrm{ft}_{\mathrm{t}}$ are forecast net inflows. InstShare $\mathrm{ft}_{1-1}$ is the percentage of a fund's net assets held by institutional shareholders. Con $\mathrm{f}_{\mathrm{f}}$ is a dummy variable which takes a value of one for constrained funds and zero for unconstrained funds. Constrained funds are funds that held less than $30 \%$ weekly liquidity before the reform in 2009Q4. Unconstrained funds are the funds that held more than or equal to $30 \%$ weekly liquidity before the reform in 2009Q4. All funds that entered the sample only after the reform are classified as constrained or unconstrained as described in the definition of the $\mathrm{Con}_{\mathrm{f}}$ dummy in Appendix A.1. Size $\mathrm{ft}$ is the $\log$ of the net assets of a fund. All variables are winsorised at the $1^{\text {st }}$ and $99^{\text {th }}$ percentiles. In all regressions, we calculate bootstrapped standard errors which are clustered by funds (see Appendix A.1 for detailed definitions of all the variables). Significance levels are indicated by $* * * p<0.01, * * p<0.05$ and $* p<0.1$. 
Table 7. Distribution of Eurozone Share of MMFs

\begin{tabular}{ccc}
\hline \hline & \multicolumn{2}{c}{ Eurozone Share, EZB $\mathbf{E Z}_{\mathrm{ft}}(\boldsymbol{\%})$} \\
Calm & Crisis \\
\cline { 2 - 3 } SD & 15.82 & 11.95 \\
Min & 8.36 & 8.42 \\
Max & 0.00 & 0.00 \\
p1 & 40.41 & 38.40 \\
p5 & 0.00 & 0.00 \\
p10 & 1.74 & 0.00 \\
p25 & 4.66 & 1.52 \\
p50 & 9.05 & 4.88 \\
p75 & 16.78 & 11.08 \\
p90 & 22.01 & 17.72 \\
p95 & 26.39 & 24.69 \\
p99 & 28.70 & 28.16 \\
N & 34.81 & 31.20 \\
\hline \hline
\end{tabular}

This table presents the distribution of Eurozone share, $\mathrm{EZB}_{\mathrm{ft}}$ which is the share of a fund's portfolio invested in the Eurozone banks that were part of the 2011 stress tests run by the European Banking Authority. The distribution is shown separately for the calm period (February 2011-May 2011) and crisis period (June 2011-September 2011). 
Table 8. Investors' Response to MMF Liquidity

\begin{tabular}{|c|c|c|c|c|c|c|}
\hline \multirow[b]{2}{*}{ DepVar: NetInflowsft } & \multicolumn{3}{|c|}{ Panel A: Weekly Liquidity } & \multicolumn{3}{|c|}{ Panel B: Daily Liquidity } \\
\hline & (1) & (2) & (3) & (4) & (5) & (6) \\
\hline \multirow[t]{2}{*}{$\mathrm{EZB}_{\mathrm{ft}-1}$} & $0.150 * *$ & $0.130 *$ & $0.119 * * *$ & $0.151 * *$ & $0.132 *$ & $0.130 * * *$ \\
\hline & $(0.064)$ & $(0.070)$ & $(0.046)$ & $(0.062)$ & $(0.067)$ & $(0.043)$ \\
\hline \multirow[t]{2}{*}{$\mathrm{EZB}_{\mathrm{ft}-1} *$ Crisist } & $-0.292 * * *$ & $-0.299 * * *$ & $-0.304 * * *$ & $-0.300 * * *$ & $-0.311 * * *$ & $-0.306 * * *$ \\
\hline & $(0.094)$ & $(0.095)$ & $(0.095)$ & $(0.084)$ & $(0.084)$ & $(0.086)$ \\
\hline \multirow[t]{2}{*}{ WLiq $\mathrm{ft}-1$} & -0.023 & -0.026 & $-0.039 *$ & & & \\
\hline & $(0.042)$ & $(0.042)$ & $(0.024)$ & & & \\
\hline \multirow[t]{2}{*}{ WLiq $\mathrm{ft}-1 *$ Crisist } & 0.031 & 0.045 & $0.062 * *$ & & & \\
\hline & $(0.035)$ & $(0.034)$ & $(0.030)$ & & & \\
\hline \multirow[t]{2}{*}{ Low $\mathrm{EZB}_{\mathrm{ft}-1} * \mathrm{WLiq}_{\mathrm{ft}-1} *$ Crisis $_{\mathrm{t}}$} & -0.006 & -0.004 & -0.022 & & & \\
\hline & $(0.022)$ & $(0.022)$ & $(0.018)$ & & & \\
\hline \multirow[t]{2}{*}{ High $\mathrm{EZB}_{\mathrm{ft}-1} *$ WLiq $_{\mathrm{ft}-1} *$ Crisist $_{\mathrm{t}}$} & $-0.052 * *$ & $-0.039 *$ & $-0.035 *$ & & & \\
\hline & $(0.022)$ & $(0.022)$ & $(0.022)$ & & & \\
\hline \multirow[t]{2}{*}{$\operatorname{DLiq}_{\mathrm{ft}-1}$} & & & & -0.052 & -0.056 & -0.042 \\
\hline & & & & $(0.054)$ & $(0.055)$ & $(0.028)$ \\
\hline \multirow[t]{2}{*}{ DLiq $_{\mathrm{ft}-1} *$ Crisis $_{\mathrm{t}}$} & & & & 0.056 & 0.062 & $0.062 *$ \\
\hline & & & & $(0.040)$ & $(0.040)$ & $(0.036)$ \\
\hline \multirow[t]{2}{*}{ Low $\mathrm{EZB}_{\mathrm{ft}-1} *$ DLiq $_{\mathrm{ft}-1} *$ Crisist $_{\mathrm{t}}$} & & & & -0.008 & -0.005 & -0.031 \\
\hline & & & & $(0.027)$ & $(0.027)$ & $(0.024)$ \\
\hline \multirow[t]{2}{*}{ High $\mathrm{EZB}_{\mathrm{ft}-1} * \mathrm{DLiq}_{\mathrm{ft}-1} *$ Crisist } & & & & $-0.087 * *$ & $-0.068^{*}$ & $-0.062 *$ \\
\hline & & & & $(0.035)$ & $(0.035)$ & $(0.035)$ \\
\hline \multirow[t]{2}{*}{ NetYield $f_{f t-1}$} & 0.255 & $0.328 *$ & $0.173 * * *$ & 0.275 & $0.342 * *$ & $0.172 * * *$ \\
\hline & $(0.168)$ & $(0.170)$ & $(0.056)$ & $(0.169)$ & $(0.171)$ & $(0.056)$ \\
\hline \multirow[t]{2}{*}{ NetYield $_{\mathrm{ft}-1} *$ Crisist } & $-0.238 *$ & -0.163 & $-0.168 *$ & $-0.216 *$ & -0.146 & $-0.174 *$ \\
\hline & $(0.129)$ & $(0.129)$ & $(0.092)$ & $(0.127)$ & $(0.130)$ & $(0.091)$ \\
\hline \multirow[t]{2}{*}{ ERatioft-1 } & 0.057 & 0.067 & -0.036 & 0.055 & 0.066 & -0.043 \\
\hline & $(0.063)$ & $(0.071)$ & $(0.034)$ & $(0.065)$ & $(0.072)$ & $(0.036)$ \\
\hline \multirow[t]{2}{*}{ ERatioft $-1^{*}$ Crisis $\mathrm{t}_{\mathrm{t}}$} & $0.143 * *$ & $0.187 * * *$ & $0.116^{*}$ & $0.168 * *$ & $0.210 * * *$ & $0.113^{*}$ \\
\hline & $(0.065)$ & $(0.066)$ & $(0.066)$ & $(0.069)$ & $(0.072)$ & $(0.067)$ \\
\hline \multirow[t]{2}{*}{ InstShare $_{\mathrm{ft}-1}$} & $-1.014 * * *$ & $-0.991 * * *$ & $0.014 *$ & $-0.997 * * *$ & $-0.978 * * *$ & $0.014^{*}$ \\
\hline & $(0.213)$ & $(0.219)$ & $(0.008)$ & $(0.209)$ & $(0.214)$ & $(0.008)$ \\
\hline InstShare $_{\mathrm{ft}-1} *$ Crisist & -0.007 & -0.006 & -0.007 & -0.006 & -0.005 & -0.007 \\
\hline & $(0.013)$ & $(0.013)$ & $(0.012)$ & $(0.013)$ & $(0.013)$ & $(0.012)$ \\
\hline Crisist & 2.558 & -1.097 & -2.378 & 1.958 & -1.093 & -1.107 \\
\hline & $(2.969)$ & (3.173) & $(3.072)$ & $(2.737)$ & $(3.014)$ & $(2.659)$ \\
\hline Con $_{\mathrm{f}} *$ Crisist & & & 1.841 & & & 1.739 \\
\hline & & & $(1.127)$ & & & $(1.148)$ \\
\hline $\mathrm{Con}_{\mathrm{f}}$ & & & $-1.122 *$ & & & $-1.119 *$ \\
\hline & & & $(0.669)$ & & & $(0.677)$ \\
\hline Size $_{\mathrm{ft}-1}$ & & & $-0.421 * * *$ & & & $-0.419 * * *$ \\
\hline & & & $(0.122)$ & & & $(0.117)$ \\
\hline Constant & $79.873 * * *$ & $78.330 * * *$ & $9.068 * * *$ & $78.822 * * *$ & $77.505 * * *$ & $8.373 * * *$ \\
\hline & $(17.768)$ & $(18.134)$ & $(3.204)$ & $(17.439)$ & $(17.745)$ & $(2.939)$ \\
\hline Fund Fixed Effects & $\mathrm{Y}$ & $\mathrm{Y}$ & $\mathrm{N}$ & $\mathrm{Y}$ & $\mathrm{Y}$ & $\mathrm{N}$ \\
\hline Time Fixed Effects & $\mathrm{N}$ & $\mathrm{Y}$ & Y & $\mathrm{N}$ & Y & Y \\
\hline Adjusted $\mathrm{R}^{2}$ & 0.0930 & 0.109 & 0.103 & 0.0951 & 0.123 & 0.103 \\
\hline Observations & 1,311 & 1,311 & 1,311 & 1,311 & 1,311 & 1,311 \\
\hline Wald Tests: & & & & & & \\
\hline $\mathrm{EZB}_{\mathrm{ft}-1}(1+$ Crisist $)$ & $-0.142 *$ & $-0.169 * *$ & $-0.185 * * *$ & $-0.149 * *$ & $-0.179 * *$ & $-0.176^{* * *}$ \\
\hline $\mathrm{xLiqft}-1(1+$ Crisist $)$ & 0.008 & 0.019 & 0.023 & 0.004 & 0.006 & 0.02 \\
\hline $\mathrm{xLiqft}-1_{\text {[Crisist }}\left(1+\right.$ Low EZB $\left.\left._{\mathrm{ft}-1}\right)\right]$ & 0.025 & 0.041 & 0.04 & 0.048 & 0.057 & 0.031 \\
\hline $\mathrm{xLiq}_{\mathrm{ft}-1}\left[\right.$ Crisist $\left._{\mathrm{t}}\left(1+\operatorname{High~EZB~}_{\mathrm{ft}-1}\right)\right]$ & -0.021 & 0.006 & 0.027 & -0.031 & -0.006 & 0 \\
\hline $\mathrm{xLiq}_{\mathrm{ft}-1}\left[1+\operatorname{Crisist}\left(1+\right.\right.$ Low EZB $\left.\left._{\mathrm{ft}-1}\right)\right]$ & 0.002 & 0.015 & 0.001 & -0.004 & 0.001 & -0.011 \\
\hline $\mathrm{xLiq}_{\mathrm{ft}-1}\left[1+\right.$ Crisist $_{\mathrm{t}}\left(1+\right.$ High EZB $\left.\left._{\mathrm{ft}-1}\right)\right]$ & -0.044 & -0.02 & -0.012 & -0.083 & -0.062 & -0.042 \\
\hline
\end{tabular}




\begin{tabular}{lcccccc} 
NetYield $\mathrm{ft}_{-1}(1+\mathrm{Crisis} \mathrm{t})$ & 0.017 & 0.165 & 0.005 & 0.059 & 0.196 & -0.002 \\
ERatioft-1 (1+Crisist) & $0.200^{* * *}$ & $0.254^{* * *}$ & 0.08 & $0.223 * * *$ & $0.276^{* * *}$ & 0.07 \\
InstShareft-1 (1+Crisist) & -1.021 & -0.997 & 0.007 & -1.003 & -0.983 & 0.007 \\
Con $_{\mathrm{f}}(1+\mathrm{Crisist})$ & & & 0.719 & & 0.62 \\
\hline
\end{tabular}

This table presents the results of panel regressions that measure investors' response to MMF liquidity. The sample includes the calm period (February 2011-May 2011) and crisis period (June 2011-September 2011). The dependent variable is NetInflows $\mathrm{ft}_{\mathrm{ft}}$, which is the difference between the monthly fund-level subscriptions and redemptions scaled by lagged net assets. $\mathrm{EZB}_{\mathrm{ft}}$ is the share of a fund's portfolio invested in the Eurozone banks that were part of 2011 stress tests run by the European Banking Authority. Low EZB $\mathrm{ft}_{\mathrm{ft}}$ and High $\mathrm{EZB}_{\mathrm{ft}}$ are dummy variables which take a value of one for the funds that belong to the lowest and highest EZB $\mathrm{B}_{\mathrm{ft}}$ terciles, respectively. The Crisis $\mathrm{d}_{\mathrm{t}}$ ummy takes a value of one for the crisis period (June 2011-September 2011) and a value of zero for the calm period (February 2011-May 2011). WLiq ${ }_{\mathrm{ft}}\left(\mathrm{DLiq}_{\mathrm{ft}}\right.$ ) represents the weekly (daily) liquid assets of a fund as the percentage of its total portfolio of securities. NetYield $\mathrm{ft}_{-1}$ is the value-weighted average of the 7-day net yields of share classes as reported on the N-MFP forms. It represents the difference between the gross yield and a fund's expenses. ERatio $\mathrm{ft}_{1}$ is the expense ratio of a fund, calculated as the difference between its gross and net yields. Gross Yield $\mathrm{ft}_{\mathrm{ft}}$ is the value-weighted average of issuer yields. InstShare $\mathrm{ft}_{\mathrm{ft}}$ the percentage of a fund's net assets held by institutional shareholders (i.e. shareholders who have a minimum investment requirement of $\$ 1,000,000)$. Con $_{\mathrm{f}}$ is a dummy variable which takes a value of one for constrained funds and zero for unconstrained funds. Constrained funds are funds that held less than $30 \%$ weekly liquidity before the reform in 2009Q4. Unconstrained funds are the funds that held more than or equal to $30 \%$ weekly liquidity before the reform in 2009Q4. All funds that entered the sample only after the reform are classified as constrained or unconstrained as described in the definition of the Con $_{\mathrm{f}}$ dummy in Appendix A.1. Size $\mathrm{ft}_{\mathrm{ft}}$ is the $\log$ of the net assets of a fund. All variables are winsorised at the $1^{\text {st }}$ and $99^{\text {th }}$ percentiles. In all regressions, the standard errors are clustered by funds (see Appendix A.1 for detailed definitions of all the variables). Significance levels are indicated by $* * * \mathrm{p}<0.01, * * \mathrm{p}<0.05$ and $* \mathrm{p}<0.1$. 


\section{APPENDIX}

\section{A.1: Variables Definitions}

\begin{tabular}{|c|c|}
\hline VARIABLE & DEFINITION \\
\hline $\operatorname{AgcyLiq}_{\mathrm{ft}}(\%)$ & $\begin{array}{l}\text { The percentage of total portfolio assets invested in US government agency securities } \\
\text { maturing within } 60 \text { days. }\end{array}$ \\
\hline $\operatorname{Con}_{\mathrm{f}}$ & 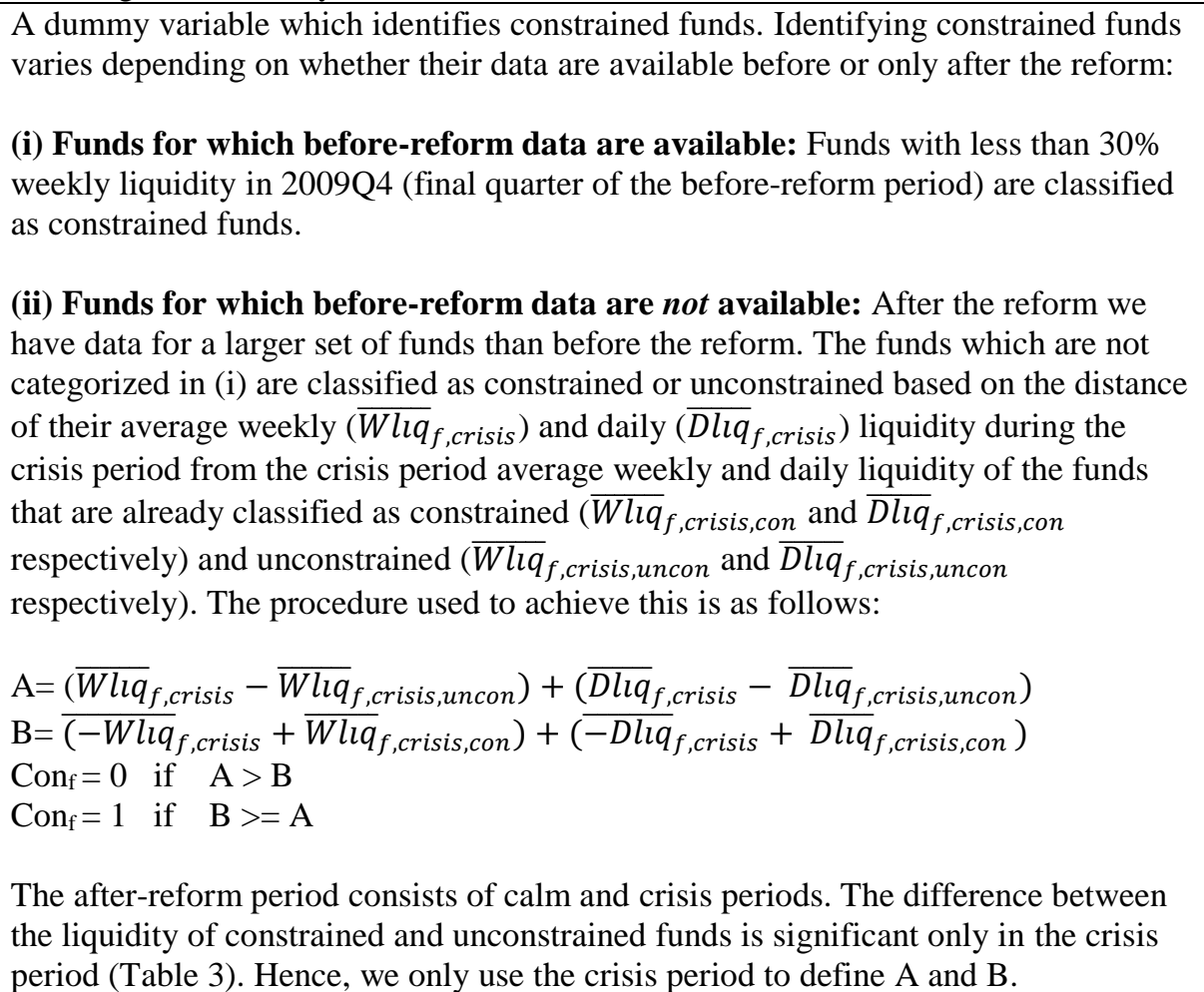 \\
\hline $\operatorname{DLiq}_{\mathrm{ft}}(\%)$ & $\begin{array}{l}\text { Represents the daily liquid assets of a fund as a percentage of its total portfolio of } \\
\text { securities. DLiq } \mathrm{q}_{\mathrm{ft}} \text { includes any security that matures or has a demand feature that } \\
\text { allows it to be converted to cash within } 1 \text { business day and US Treasury securities of } \\
\text { any maturity. }\end{array}$ \\
\hline ERatio $_{\mathrm{ft}}(\mathrm{bp})$ & $=$ GrossYield $_{\mathrm{ft}}-$ NetYield $_{\mathrm{ft}}$ \\
\hline $\mathrm{ELM}_{\mathrm{ft}}(\mathrm{bp})$ & 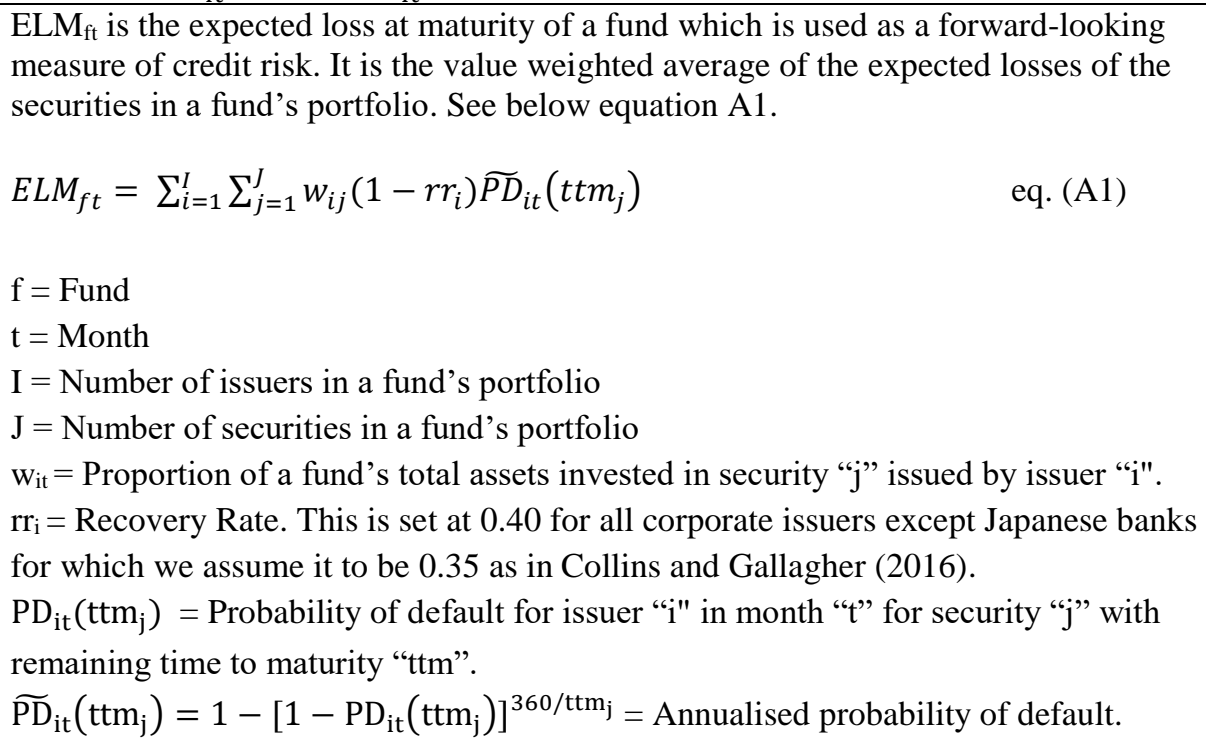 \\
\hline
\end{tabular}




\begin{tabular}{|c|c|}
\hline $\operatorname{ExDLiq}_{\mathrm{ft}}(\%)$ & $=\frac{\text { DLiq }_{\mathrm{f}, \mathrm{t}-1}}{\text { NetAssets }_{\mathrm{f}, \mathrm{t}-1}}-\frac{\overline{\text { Outflows }}_{\mathrm{f}, \mathrm{crisis}}}{\text { NetAssets }_{\mathrm{f}, \mathrm{t}-1}}$. \\
\hline $\operatorname{ExWLiq}_{\mathrm{ft}}(\%)$ & $=\frac{\text { WLiq }_{\mathrm{f}, \mathrm{t}-1}}{\text { NetAssets }_{\mathrm{f}, \mathrm{t}-1}}-{\overline{\text { Outflows }_{\mathrm{f}, \mathrm{crisis}}}}_{\text {NetAssets }_{\mathrm{f}, \mathrm{t}-1}}$ \\
\hline ExpInflows $_{\mathrm{ft}}(\%)$ & $\begin{array}{l}\text { Is given by predicted NetInflows } \mathrm{ft}_{\mathrm{t}} \text { if the predicted value is greater than or equal to } \\
\text { zero and zero otherwise. Predictions are obtained with an } \operatorname{AR}(1) \text { regression on } \\
\text { NetInflows. }\end{array}$ \\
\hline ExpOutflows $_{\mathrm{ft}}(\%)$ & $\begin{array}{l}\text { Is given by minus predicted NetInflows } \mathrm{ft}_{\mathrm{f}} \text { if the predicted value is less than zero and } \\
\text { zero otherwise. Predictions are obtained with an } \operatorname{AR}(1) \text { regression on NetInflows. }\end{array}$ \\
\hline $\mathrm{EZB}_{\mathrm{ft}}(\%)$ & $\begin{array}{l}=\frac{\sum_{\mathrm{i} \in \mathrm{EBank}} \text { OutstandingAmount }_{\mathrm{f}, \mathrm{i}, \mathrm{t}}}{\sum_{\mathrm{i}} \text { OutstandingAmount }_{\mathrm{f}, \mathrm{i}, \mathrm{t}}} \text {, EBank includes Eurozone banks that were part of } \\
2011 \text { stress tests run by the European Banking Authority. }\end{array}$ \\
\hline FlowVol $_{\mathrm{ft}}(\%)$ & $\begin{array}{l}=\text { Rolling Standard deviation of NetInflows } \\
\text { the past } 7 \text {-month observations. }\end{array}$ \\
\hline GrossYield $_{\mathrm{ft}}(\mathrm{bp})$ & $\begin{array}{l}\text { Value-weighted average of issuer yields: } \\
=\frac{\sum_{\mathrm{i}=1}^{\mathrm{n}} \text { IssuerYield }_{\mathrm{it}} \times \text { OutstandingAmount }_{\mathrm{it}}}{\sum_{\mathrm{i}=1}^{\mathrm{n}} \text { OutstandingAmount }_{\mathrm{it}}}\end{array}$ \\
\hline InstShare $_{\mathrm{ft}}(\%)$ & $\begin{array}{l}\text { The share of a fund's assets in institutional share classes. We define institutional } \\
\text { share classes as the share classes that have minimum investment of } \$ 1,000,000 \text { or } \\
\text { that have "institutional" in the name of the class. }\end{array}$ \\
\hline IssuerYield $_{\text {it }}(\mathrm{bp})$ & The yield of invested security as reported on the form N-MFP filed with the SEC. \\
\hline NetAssets $_{\mathrm{ft}}(\$)$ & $\begin{array}{l}\text { NetAssets }{ }_{\mathrm{ft}} \text { is the value of net assets reported on the N-MFP form and is the total } \\
\text { value of a fund's securities and other assets less liabilities. }\end{array}$ \\
\hline NetInflows $_{\mathrm{ft}}(\%)$ & $=\frac{\left(\text { Subscriptions }_{\mathrm{ft}}-\text { Redemptions }_{\mathrm{ft}}\right) * 100}{\text { NetAssets }_{\mathrm{ft}-1}}$ \\
\hline NetYield $_{\mathrm{ft}}(\mathrm{bp})$ & $\begin{array}{l}\text { NetYield }{ }_{\mathrm{ft}} \text { is the value-weighted average of the 7-day net yields of a fund's share } \\
\text { classes as reported on the N-MFP forms. }\end{array}$ \\
\hline NonGovLiq $\mathrm{ft}(\%)$ & $\begin{array}{l}\text { Includes the percentage of total portfolio assets invested in securities maturing within } \\
5 \text { days, excluding government and agency securities. }\end{array}$ \\
\hline $\mathrm{OA}_{0-3 \mathrm{~m}, \mathrm{ft}}(\%)$ & $\begin{array}{l}\text { The percentage of total portfolio assets invested in securities with maturities less than } \\
\text { or equal to } 90 \text { days. }\end{array}$ \\
\hline $\mathrm{OA}_{9-13 \mathrm{~m}, \mathrm{ft}}(\%)$ & $\begin{array}{l}\text { The percentage of total portfolio assets invested in securities with maturities ranging } \\
\text { between } 270 \text { and } 397 \text { days. }\end{array}$ \\
\hline PortRisk $_{\mathrm{ft}}(\mathrm{bp})$ & $\begin{array}{l}=\text { GrossYield }_{\mathrm{ft}}-\text { Tbill }_{\mathrm{t}} \\
\left(\text { Tbill }_{\mathrm{t}}=4-\text { Week Treasury bill, secondary market rate, percent, monthly) }\right.\end{array}$ \\
\hline Size $_{\mathrm{ft}}$ & $=\log \left(\right.$ NetAssets $\left._{\mathrm{ft}}\right)$ \\
\hline Spread $_{0-3 m, f t}(b p)$ & $\begin{array}{l}\text { Measures the difference between the weighted issuer yield of securities maturing } \\
\text { within } 3 \text { months and the } 3 \text {-month Treasury bill. }\end{array}$ \\
\hline $\operatorname{Spread}_{9-13 \mathrm{~m}, \mathrm{ft}}(\mathrm{bp})$ & $\begin{array}{l}\text { Measures the difference between the weighted issuer yield of securities maturing } \\
\text { within } 3 \text { months and the 12-month Treasury bill. }\end{array}$ \\
\hline $\operatorname{Treasury}_{\mathrm{ft}}(\%)$ & $\begin{array}{l}\text { The percentage of total portfolio assets invested in US Treasury securities of any } \\
\text { maturity. }\end{array}$ \\
\hline $\mathrm{WAL}_{\mathrm{ft}}$ (days) & $\begin{array}{l}\text { It is the weighted average life calculated as the dollar-weighted average maturity of a } \\
\text { fund's portfolio holdings without regard to interest rate reset dates. } \\
=\frac{\sum_{\mathrm{i}} \text { AmortizedCost }_{\text {it }} \times \text { TimeToMaturity }_{\mathrm{it}}}{\sum_{\mathrm{i}} \text { AmortizedCost }_{\text {it }}} \\
\mathrm{i}=\text { security held in a fund's portfolio. }\end{array}$ \\
\hline $\mathrm{WLiq}_{\mathrm{ft}}(\%)$ & $\begin{array}{l}\text { Represents the weekly liquid assets of a fund as a percentage of its total portfolio of } \\
\text { securities. WLiq } \mathrm{ft}_{\mathrm{ft}} \text { includes any security that matures or has a demand feature that } \\
\text { allows it to be converted to cash within } 5 \text { business days, US government agency } \\
\text { securities that mature within } 60 \text { days, and US Treasury securities of any maturity. }\end{array}$ \\
\hline Internal_Wit $t_{\mathrm{f}}$ & $\begin{array}{l}\text { A dummy variable that is equal to one if more than } 20 \% \text { of the MMF is beneficially } \\
\text { held by affiliated entities at the beginning of the sample period. We construct it by } \\
\text { identifying internal funds in our sample by name and matching them with the internal } \\
\text { funds identified in Witmer ( } 2018 \text {, Table } 1) \text {. Our sample includes } 21 \text { internal funds. }\end{array}$ \\
\hline Institutional_Wit $f(\%)$ & $\begin{array}{l}\text { The share of a fund's net assets in institutional share classes. A share class is } \\
\text { classified as institutional if it has a minimum investment of } \$ 100,000 \text { or if its fund } \\
\text { fees are below } 10 \text { basis points for the entire sample period. }\end{array}$ \\
\hline
\end{tabular}


A.2. Impact of "Know Your Investor” Requirement (Dynamic Panel, System GMM)

\begin{tabular}{|c|c|c|c|c|}
\hline \multirow[b]{2}{*}{ Dep Var: } & \multicolumn{2}{|c|}{ Panel A } & \multicolumn{2}{|c|}{ Panel B } \\
\hline & $\begin{array}{l}\text { WLiqfit } \\
\text { (1) }\end{array}$ & $\begin{array}{l}\text { DLiqft } \\
\text { (2) }\end{array}$ & $\begin{array}{l}\text { WLiqft } \\
\text { (3) }\end{array}$ & $\begin{array}{l}\text { DLiqfit } \\
\text { (4) }\end{array}$ \\
\hline ExpOutflows $_{\mathrm{ft}-1} *$ Crisis $_{\mathrm{t}}$ & $\begin{array}{c}4.725 * * * \\
(1.601)\end{array}$ & $\begin{array}{c}4.344 * * * \\
(1.511)\end{array}$ & $\begin{array}{c}4.606 * * * \\
(1.706)\end{array}$ & $\begin{array}{c}4.378 * * \\
(1.722)\end{array}$ \\
\hline ExpOutflows $\mathrm{ft}_{\mathrm{ft}}$ & $\begin{array}{l}-0.220 \\
(0.203)\end{array}$ & $\begin{array}{c}-0.367 * * \\
(0.170)\end{array}$ & $\begin{array}{l}-0.126 \\
(0.189)\end{array}$ & $\begin{array}{l}-0.350 * \\
(0.182)\end{array}$ \\
\hline PortRisk $_{\mathrm{ft}-1} *$ Crisis $_{\mathrm{t}}$ & $\begin{array}{c}0.216 \\
(0.230)\end{array}$ & $\begin{array}{c}0.380 * * \\
(0.188)\end{array}$ & & \\
\hline PortRisk $_{\mathrm{ft}-1}$ & $\begin{array}{c}-0.864 * * * \\
(0.267)\end{array}$ & $\begin{array}{c}-0.626 * * * \\
(0.192)\end{array}$ & & \\
\hline ELM $_{\mathrm{ft}-1} *$ Crisis $_{\mathrm{t}}$ & & & $\begin{array}{c}0.877 * * \\
(0.396)\end{array}$ & $\begin{array}{c}0.177 \\
(0.416)\end{array}$ \\
\hline $\mathrm{ELM}_{\mathrm{ft}-1}$ & & & $\begin{array}{c}-1.422 * * * \\
(0.372)\end{array}$ & $\begin{array}{l}-0.610 \\
(0.433)\end{array}$ \\
\hline Flow Vol $_{\mathrm{ft}-1} *$ Crisis $_{\mathrm{t}}$ & $\begin{array}{c}0.325 \\
(0.235)\end{array}$ & $\begin{array}{c}0.406 * * \\
(0.160)\end{array}$ & $\begin{array}{c}0.222 \\
(0.230)\end{array}$ & $\begin{array}{l}0.413 * * \\
(0.164)\end{array}$ \\
\hline FlowVol $_{\mathrm{ft}-1}$ & $\begin{array}{l}-0.0850 \\
(0.169)\end{array}$ & $\begin{array}{c}-0.0694 \\
(0.128)\end{array}$ & $\begin{array}{c}0.036 \\
(0.145)\end{array}$ & $\begin{array}{l}-0.044 \\
(0.154)\end{array}$ \\
\hline ExpInflows $_{\mathrm{ft}-1} *$ Crisis $_{\mathrm{t}}$ & $\begin{array}{c}0.989 \\
(0.656)\end{array}$ & $\begin{array}{c}1.696^{* * *} \\
(0.574)\end{array}$ & $\begin{array}{l}1.186 * \\
(0.712)\end{array}$ & $\begin{array}{c}1.715^{* * *} \\
(0.649)\end{array}$ \\
\hline ExpInflows & $\begin{array}{l}-0.279 \\
(0.586)\end{array}$ & $\begin{array}{c}-0.579 * \\
(0.315)\end{array}$ & $\begin{array}{l}-0.279 \\
(0.596)\end{array}$ & $\begin{array}{l}-0.601 \\
(0.400)\end{array}$ \\
\hline InstShare $_{\mathrm{ft}-1}$ & $\begin{array}{c}-0.00639 \\
(0.0147)\end{array}$ & $\begin{array}{l}-0.0251 * \\
(0.0144)\end{array}$ & $\begin{array}{l}-0.010 \\
(0.015)\end{array}$ & $\begin{array}{l}-0.022 \\
(0.017)\end{array}$ \\
\hline Crisis $_{\mathrm{t}}$ & $\begin{array}{c}4.402 \\
(3.228)\end{array}$ & $\begin{array}{c}-10.21 * * * \\
(2.489)\end{array}$ & $\begin{array}{c}2.443 \\
(3.102)\end{array}$ & $\begin{array}{c}-7.760 * * * \\
(2.685)\end{array}$ \\
\hline WLiqft-1 $_{\mathrm{f}}$ & $\begin{array}{c}0.352^{* * * *} \\
(0.109)\end{array}$ & & $\begin{array}{c}0.438 * * * \\
(0.087)\end{array}$ & \\
\hline $\operatorname{DLiq}_{\mathrm{ft}-1}$ & & $\begin{array}{c}0.0788 \\
(0.0627)\end{array}$ & & $\begin{array}{c}0.061 \\
(0.063)\end{array}$ \\
\hline $\operatorname{Con}_{\mathrm{f}} *$ Crisis $_{\mathrm{t}}$ & $\begin{array}{c}-10.80 * * * \\
(2.603)\end{array}$ & $\begin{array}{l}-3.204 * \\
(1.825)\end{array}$ & $\begin{array}{c}-10.739 * * * \\
(2.596)\end{array}$ & $\begin{array}{l}-2.367 \\
(2.103)\end{array}$ \\
\hline $\operatorname{Con}_{\mathrm{f}}$ & $\begin{array}{l}-0.556 \\
(2.131)\end{array}$ & $\begin{array}{l}-1.958 \\
(1.554)\end{array}$ & $\begin{array}{l}-3.104 \\
(2.268)\end{array}$ & $\begin{array}{c}-3.700 * * \\
(1.736)\end{array}$ \\
\hline Size $_{\mathrm{ft}-1}$ & $\begin{array}{l}-0.635^{*} \\
(0.377)\end{array}$ & $\begin{array}{l}-0.348 \\
(0.256)\end{array}$ & $\begin{array}{c}-0.865^{* *} \\
(0.341)\end{array}$ & $\begin{array}{l}-0.461 \\
(0.309)\end{array}$ \\
\hline Constant & $\begin{array}{c}43.24 * * * \\
(11.70)\end{array}$ & $\begin{array}{c}24.15^{* * * *} \\
(5.327)\end{array}$ & $\begin{array}{c}44.448 * * * \\
(9.930)\end{array}$ & $\begin{array}{c}24.749 * * * \\
(6.566)\end{array}$ \\
\hline Fund Fixed Effects & $\mathrm{Y}$ & $\mathrm{Y}$ & $\mathrm{Y}$ & $\mathrm{Y}$ \\
\hline Time Fixed Effects & Y & Y & Y & Y \\
\hline Observations & 1,195 & 1,195 & 1,195 & 1,195 \\
\hline Wald Tests: & & & & \\
\hline $\begin{array}{l}\text { ExpOutflows }_{\mathrm{ft}-1}\left(1+\text { Crisis }_{\mathrm{t}}\right) \\
\text { PortRisk }_{\mathrm{ft}-1}\left(1+\text { Crisis }_{\mathrm{t}}\right)\end{array}$ & $\begin{array}{l}4.505 * * * \\
-0.648 * * *\end{array}$ & $\begin{array}{l}3.977 * * \\
-0.246 * *\end{array}$ & $4.480 * * *$ & $4.028 * *$ \\
\hline $\mathrm{ELM}_{\mathrm{ft}-1}\left(1+\right.$ Crisis $\left._{\mathrm{t}}\right)$ & & & $-0.545^{* *}$ & $-0.433 *$ \\
\hline FlowVol $_{\mathrm{ft}-1}\left(1+\right.$ Crisis $\left._{\mathrm{t}}\right)$ & 0.240 & $0.337 * *$ & 0.258 & $0.369 * *$ \\
\hline ExpInflows ft-1 $_{\left(1+\text { Crisis }_{\mathrm{t}}\right)}$ & 0.710 & 1.117 & $0.907 *$ & $1.114 * *$ \\
\hline $\operatorname{Con}_{\mathrm{f}}\left(1+\right.$ Crisis $\left._{t}\right)$ & $-11.356 * * *$ & $-5.162 * * *$ & $-13.843 * * *$ & $-6.067 * * *$ \\
\hline "GMM Specification Tests: & & & & \\
\hline $\mathrm{AB}$ test for $\mathrm{AR}(1)$ in first differences & 0.000 & 0.000 & 0.000 & 0.000 \\
\hline $\mathrm{AB}$ test for $\mathrm{AR}(2)$ in first differences & 0.619 & 0.948 & 0.539 & 0.870 \\
\hline Hansen Test & 0.061 & 0.141 & 0.259 & 0.178 \\
\hline
\end{tabular}

This table presents the results of dynamic panel regressions that test the 'know your investor' requirement. Models are estimated using system generalized method of moments (GMM). Results are computed for weekly (WLiq $\mathrm{ft}_{\mathrm{t}}$ ) 
and daily $\left(\mathrm{DLiq}_{\mathrm{ft}}\right)$ liquidity by using two alternative portfolio risk measures, PortRisk $\mathrm{ft}\left(\right.$ Panel A) and ELM $\mathrm{ft}_{\mathrm{ft}}(\mathrm{Panel}$ B). The sample includes the crisis period (June 2011-September 2011) and calm period (September 2013-

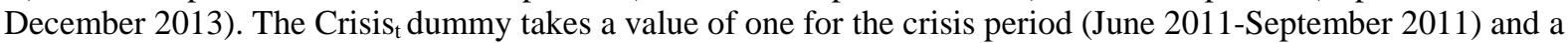
value of zero for the calm period (September 2013-December 2013). The ExpOutflows are the forecast net outflows. PortRisk $\mathrm{ft}_{\mathrm{ft}}$ measures the difference between the gross yield of the fund portfolio and the 1-month Treasury bill. ELM $\mathrm{ft}_{\mathrm{ft}}$ is the expected loss at maturity of a fund computed as the value weighted average of the expected losses of the securities in the fund's portfolio. FlowVol $\mathrm{ft}_{\mathrm{f}}$ is the rolling standard deviation of NetInflows $\mathrm{ft}$ of a fund. NetInflows $\mathrm{ft}_{\mathrm{ft}}$ is the difference between the monthly fund-level subscriptions and redemptions scaled by lagged net assets. ExpInflows $\mathrm{ft}_{\mathrm{ft}}$ are forecast net inflows. InstShare $\mathrm{ft}_{\mathrm{ft}-1}$ is the percentage of a fund's net assets held by institutional shareholders. $\mathrm{Con}_{\mathrm{f}}$ is a dummy variable which takes a value of one for constrained funds and zero for unconstrained funds. Constrained funds are funds that held less than $30 \%$ weekly liquidity before the reform in 2009Q4. Unconstrained funds are the funds that held more than or equal to $30 \%$ weekly liquidity before the reform in 2009Q4. All funds that entered the sample only after the reform are classified as constrained or unconstrained as described in the definition of the $\mathrm{Con}_{\mathrm{f}}$ dummy in Appendix A.1. Size $\mathrm{ft}$ is the $\log$ of the net assets of a fund. All variables are winsorised at the $1^{\text {st }}$ and $99^{\text {th }}$ percentiles. In all regressions, the Windmeijer corrected standard errors are reported (see Appendix A.1 for detailed definitions of all the variables). Significance levels are indicated by $* * * \mathrm{p}<0.01, * * \mathrm{p}<0.05$ and $* \mathrm{p}<0.1$. 
A.3. Investor Response to MMF Liquidity (Extended Sample Jan 2011- April 2015 and Additional Variables from Witmer (2018, Table 3))

\begin{tabular}{|c|c|c|c|c|c|c|}
\hline \multirow[b]{2}{*}{ DepVar: NetInflowsft } & \multicolumn{3}{|c|}{ Panel A: Weekly Liquidity } & \multicolumn{3}{|c|}{ Panel B: Daily Liquidity } \\
\hline & (1) & (2) & (3) & (4) & (5) & (6) \\
\hline $\mathrm{EZB}_{\mathrm{ft}-1}$ & $\begin{array}{c}0.007 \\
(0.022)\end{array}$ & $\begin{array}{l}-0.011 \\
(0.024)\end{array}$ & $\begin{array}{l}-0.019 \\
(0.019)\end{array}$ & $\begin{array}{c}0.014 \\
(0.022)\end{array}$ & $\begin{array}{l}-0.003 \\
(0.024)\end{array}$ & $\begin{array}{l}-0.004 \\
(0.017)\end{array}$ \\
\hline $\mathrm{EZB}_{\mathrm{ft}-1} *$ Crisis $_{\mathrm{t}}$ & $\begin{array}{l}-0.091 \\
(0.077)\end{array}$ & $\begin{array}{l}-0.089 \\
(0.077)\end{array}$ & $\begin{array}{l}-0.089 \\
(0.074)\end{array}$ & $\begin{array}{l}-0.115 \\
(0.073)\end{array}$ & $\begin{array}{l}-0.119 \\
(0.074)\end{array}$ & $\begin{array}{l}-0.114 \\
(0.072)\end{array}$ \\
\hline WLiqft-1 & $\begin{array}{c}-0.088 * * * \\
(0.020)\end{array}$ & $\begin{array}{c}-0.096^{* * * *} \\
(0.021)\end{array}$ & $\begin{array}{c}-0.068 * * * \\
(0.015)\end{array}$ & & & \\
\hline WLiqft-1 $*$ Crisist & $\begin{array}{c}0.068 * * \\
(0.028)\end{array}$ & $\begin{array}{c}0.072 * * \\
(0.029)\end{array}$ & $\begin{array}{c}0.067 * * \\
(0.029)\end{array}$ & & & \\
\hline Low $\mathrm{EZB}_{\mathrm{ft}} * \mathrm{WLiq}_{\mathrm{ft}-1} *$ Crisist & $\begin{array}{l}-0.016 \\
(0.021)\end{array}$ & $\begin{array}{l}-0.014 \\
(0.021)\end{array}$ & $\begin{array}{c}-0.014 \\
(0.020)\end{array}$ & & & \\
\hline High EZB $_{\mathrm{ft}} * \mathrm{WLiq}_{\mathrm{ft}-1} *$ Crisist & $\begin{array}{c}-0.060 * * * \\
(0.022)\end{array}$ & $\begin{array}{c}-0.050 * * \\
(0.022)\end{array}$ & $\begin{array}{c}-0.047 * * \\
(0.021)\end{array}$ & & & \\
\hline DLiqft-1 & & & & $\begin{array}{c}-0.077 * * * \\
(0.020)\end{array}$ & $\begin{array}{c}-0.078 * * * \\
(0.021)\end{array}$ & $\begin{array}{c}-0.052 * * * \\
(0.015)\end{array}$ \\
\hline DLiq $_{\mathrm{ft}-1} *$ Crisist & & & & $\begin{array}{c}0.044 \\
(0.028)\end{array}$ & $\begin{array}{l}0.048^{*} \\
(0.028)\end{array}$ & $\begin{array}{c}0.040 \\
(0.028)\end{array}$ \\
\hline Low $\mathrm{EZB}_{\mathrm{ft}} * \operatorname{DLiq}_{\mathrm{ft}-1} *$ Crisist & & & & $\begin{array}{l}-0.017 \\
(0.027)\end{array}$ & $\begin{array}{l}-0.017 \\
(0.027)\end{array}$ & $\begin{array}{l}-0.018 \\
(0.026)\end{array}$ \\
\hline High $\mathrm{EZB}_{\mathrm{ft}} * \mathrm{DLiq}_{\mathrm{ft}-1} *$ Crisist & & & & $\begin{array}{c}-0.058^{* * *} \\
(0.021)\end{array}$ & $\begin{array}{c}-0.047 * * \\
(0.021)\end{array}$ & $\begin{array}{c}-0.044 * * \\
(0.020)\end{array}$ \\
\hline NetYield $f_{f t-1}$ & $\begin{array}{c}0.053 * * \\
(0.025)\end{array}$ & $\begin{array}{c}0.032 \\
(0.022)\end{array}$ & $\begin{array}{c}0.061 * * \\
(0.024)\end{array}$ & $\begin{array}{c}0.056 * * \\
(0.026)\end{array}$ & $\begin{array}{l}0.045^{*} \\
(0.024)\end{array}$ & $\begin{array}{c}0.071^{* * * *} \\
(0.025)\end{array}$ \\
\hline NetYield $_{\mathrm{ft}-1} *$ Crisis $_{\mathrm{t}}$ & $\begin{array}{l}-0.137 \\
(0.086)\end{array}$ & $\begin{array}{l}-0.079 \\
(0.085)\end{array}$ & $\begin{array}{c}-0.074 \\
(0.082)\end{array}$ & $\begin{array}{c}-0.144 * \\
(0.084)\end{array}$ & $\begin{array}{l}-0.090 \\
(0.083)\end{array}$ & $\begin{array}{c}-0.091 \\
(0.080)\end{array}$ \\
\hline ERatioft-1 & $\begin{array}{c}0.019 \\
(0.020)\end{array}$ & $\begin{array}{l}-0.017 \\
(0.020)\end{array}$ & $\begin{array}{l}-0.016 \\
(0.014)\end{array}$ & $\begin{array}{c}0.018 \\
(0.020)\end{array}$ & $\begin{array}{l}-0.007 \\
(0.021)\end{array}$ & $\begin{array}{l}-0.014 \\
(0.015)\end{array}$ \\
\hline ERatioft- $1 *$ Crisist & $\begin{array}{c}0.019 \\
(0.060)\end{array}$ & $\begin{array}{c}0.062 \\
(0.060)\end{array}$ & $\begin{array}{c}0.072 \\
(0.057)\end{array}$ & $\begin{array}{c}0.017 \\
(0.062)\end{array}$ & $\begin{array}{c}0.056 \\
(0.063)\end{array}$ & $\begin{array}{c}0.063 \\
(0.059)\end{array}$ \\
\hline NetInflowsft-1 & $\begin{array}{c}-0.093 * * * \\
(0.026)\end{array}$ & $\begin{array}{c}-0.095 * * * \\
(0.026)\end{array}$ & $\begin{array}{c}-0.086 * * * \\
(0.027)\end{array}$ & $\begin{array}{c}-0.090 * * * \\
(0.026)\end{array}$ & $\begin{array}{c}-0.093 * * * \\
(0.026)\end{array}$ & $\begin{array}{c}-0.084 * * * \\
(0.028)\end{array}$ \\
\hline Crisis $_{\mathrm{t}}$ & $\begin{array}{c}1.068 \\
(2.381)\end{array}$ & $\begin{array}{l}-1.770 \\
(2.510)\end{array}$ & $\begin{array}{l}-1.582 \\
(2.582)\end{array}$ & $\begin{array}{l}3.001 * \\
(1.729)\end{array}$ & $\begin{array}{c}0.488 \\
(1.893)\end{array}$ & $\begin{array}{c}0.865 \\
(1.960)\end{array}$ \\
\hline Institutional_Witft-1 & $\begin{array}{c}0.029 \\
(0.055)\end{array}$ & $\begin{array}{c}0.029 \\
(0.055)\end{array}$ & $\begin{array}{c}0.017 * * * \\
(0.005)\end{array}$ & $\begin{array}{c}0.026 \\
(0.058)\end{array}$ & $\begin{array}{c}0.027 \\
(0.057)\end{array}$ & $\begin{array}{c}0.013 * * * \\
(0.004)\end{array}$ \\
\hline Institutional_Witft-1 $*$ Crisist & $\begin{array}{c}-0.039 * * * \\
(0.008)\end{array}$ & $\begin{array}{c}-0.040 * * * \\
(0.008)\end{array}$ & $\begin{array}{c}-0.040 * * * \\
(0.008)\end{array}$ & $\begin{array}{c}-0.037 * * * \\
(0.008)\end{array}$ & $\begin{array}{c}-0.037 * * * \\
(0.008)\end{array}$ & $\begin{array}{c}-0.038 * * * \\
(0.008)\end{array}$ \\
\hline Internal_Witt $*$ Crisist & $\begin{array}{c}1.586 \\
(1.300)\end{array}$ & $\begin{array}{c}1.641 \\
(1.301)\end{array}$ & $\begin{array}{c}1.893 \\
(1.230)\end{array}$ & $\begin{array}{c}1.542 \\
(1.250)\end{array}$ & $\begin{array}{c}1.597 \\
(1.248)\end{array}$ & $\begin{array}{c}1.930 \\
(1.200)\end{array}$ \\
\hline Conf $_{\mathrm{f}} *$ Crisist & & & $\begin{array}{l}-0.401 \\
(1.050)\end{array}$ & & & $\begin{array}{c}-0.520 \\
(1.038)\end{array}$ \\
\hline $\mathrm{Con}_{\mathrm{f}}$ & & & $\begin{array}{c}-0.776 * * \\
(0.370)\end{array}$ & & & $\begin{array}{c}-0.784 * * \\
(0.350)\end{array}$ \\
\hline Size $_{\mathrm{ft}-1}$ & & & $\begin{array}{c}-0.298 * * * \\
(0.109)\end{array}$ & & & $\begin{array}{c}-0.164 * \\
(0.095)\end{array}$ \\
\hline Constant & $\begin{array}{c}1.155 \\
(1.152)\end{array}$ & $\begin{array}{c}2.994 * * \\
(1.369)\end{array}$ & $\begin{array}{c}9.313 * * * \\
(2.860)\end{array}$ & $\begin{array}{c}0.098 \\
(1.055)\end{array}$ & $\begin{array}{c}1.273 \\
(1.225)\end{array}$ & $\begin{array}{l}4.597 * \\
(2.401)\end{array}$ \\
\hline Fund Fixed Effects & $\begin{array}{l}\mathrm{Y} \\
\mathrm{N}\end{array}$ & $\begin{array}{l}\mathrm{Y} \\
\mathrm{Y}\end{array}$ & $\begin{array}{l}\mathrm{N} \\
\mathrm{Y}\end{array}$ & $\begin{array}{l}\mathrm{Y} \\
\mathrm{N}\end{array}$ & $\begin{array}{l}\mathrm{Y} \\
\mathrm{Y}\end{array}$ & $\begin{array}{l}\mathrm{N} \\
\mathrm{Y}\end{array}$ \\
\hline Adjusted $\mathrm{R}^{2}$ & 0.0264 & 0.0470 & 0.0481 & 0.0246 & 0.0446 & 0.0447 \\
\hline Observations & 7,921 & 7,921 & 7,921 & 7,921 & 7,921 & 7,921 \\
\hline $\begin{array}{l}\text { Wald Tests: } \\
\text { EZB }_{\mathrm{ft}-1}(1+\text { Crisist })\end{array}$ & -0.084 & -0.100 & -0.108 & -0.101 & $-0.122 *$ & $-0.118^{*}$ \\
\hline
\end{tabular}




\begin{tabular}{|c|c|c|c|c|c|c|}
\hline $\mathrm{xLiq}_{\mathrm{ft}-1}\left(1+\right.$ Crisist $\left._{\mathrm{t}}\right)$ & -0.020 & -0.024 & -0.001 & -0.033 & -0.030 & -0.012 \\
\hline$x_{\text {Liq }}{ }_{\mathrm{ft}-1}\left[\operatorname{Crisist}_{\mathrm{t}}\left(1+\right.\right.$ Low EZB $\left.\left._{\mathrm{ft}}\right)\right]$ & $0.052 *$ & $0.058 * *$ & $0.053 *$ & 0.027 & 0.031 & 0.022 \\
\hline $\mathrm{xLiq}_{\mathrm{ft}-1}\left[\operatorname{Crisis}_{\mathrm{t}}\left(1+\operatorname{High}_{\mathrm{EZB}} \mathrm{ft}_{\mathrm{ft}}\right)\right]$ & 0.008 & 0.022 & 0.020 & -0.014 & 0.001 & -0.004 \\
\hline $\operatorname{xLiq}_{\mathrm{ft}-1}\left[1+\operatorname{Crisist}_{\mathrm{t}}\left(1+\operatorname{Low}_{\mathrm{EZB}}\right)\right]$ & -0.036 & -0.038 & -0.015 & -0.050 & -0.047 & -0.030 \\
\hline $\mathrm{xLiq}_{\mathrm{ft}-1}\left[1+\operatorname{Crisist}_{\mathrm{t}}\left(1+\operatorname{High}_{\mathrm{EZB}} \mathrm{ft}\right)\right]$ & $-0.080 * *$ & $-0.074 * *$ & -0.048 & $-0.091 * *$ & $-0.077 * *$ & -0.056 \\
\hline NetYield $_{\mathrm{ft}-1}\left(1+\right.$ Crisis $\left._{\mathrm{t}}\right)$ & -0.084 & -0.047 & -0.013 & -0.088 & -0.045 & -0.020 \\
\hline ERatioft-1 $\left._{(1+\text { Crisist }}\right)$ & 0.038 & 0.045 & 0.056 & 0.035 & 0.049 & 0.049 \\
\hline InstShareft-1 (1+Crisist $)$ & -0.010 & -0.011 & $-0.023 * * *$ & -0.011 & -0.010 & $-0.025 * * *$ \\
\hline $\operatorname{Con}_{\mathrm{f}}\left(1+\right.$ Crisis $\left._{\mathrm{t}}\right)$ & & & -1.177 & & & -1.304 \\
\hline
\end{tabular}

This table presents the results of panel regressions that measure investors' response to MMF liquidity with an extended sample period from January 2011 to April 2015 and the inclusion of variables used in Witmer (2018, Table 3) which are not included in our original regressions in Table 8. The dependent variable is NetInflows $\mathrm{ft}_{\mathrm{ft}}$ which is the difference between the monthly fund-level subscriptions and redemptions scaled by lagged net assets. $\mathrm{EZB}_{\mathrm{ft}}$ is the share of a fund's portfolio invested in the Eurozone banks that were part of 2011 stress tests run by the European Banking Authority. Low $\mathrm{EZB}_{\mathrm{ft}}$ and High $\mathrm{EZB}_{\mathrm{ft}}$ are dummy variables which take a value of one for the funds that belong to the lowest and highest $\mathrm{EZB}_{\mathrm{ft}}$ terciles, respectively. The Crisis $\mathrm{s}_{\mathrm{t}}$ dummy takes a value of one for the crisis period (June 2011-September 2011) and a value of zero for the calm period (February 2011-May 2011). WLiq ftt $_{\text {(Diq }}$ ) represents the weekly (daily) liquid assets of a fund as the percentage of its total portfolio of securities. NetYield $\mathrm{ft}_{-1}$ is the value-weighted average of the 7-day net yields of share classes as reported on the $\mathrm{N}-\mathrm{MFP}$ forms. It represents the difference between the gross yield and a fund's expenses. ERatio $\mathrm{ft}_{-1}$ is the expense ratio of a fund, calculated as the difference between its gross and net yields. GrossYield $\mathrm{ft}_{\mathrm{ft}}$ is the value-weighted average of issuer yields. Institutional_Wit $\mathrm{ft}_{\mathrm{ft}}$ is the dollar value of institutional share classes divided by net assets. A share class is classified as institutional if it has a minimum investment requirement of $\$ 100,000$ or if its fund fees are below 10 basis points for the entire sample period. Internal_Wit is a dummy variable that is equal to one if more than $20 \%$ of the MMF is beneficially held by affiliated entities at the beginning of the sample period. Con is a dummy variable which takes a value of one for constrained funds and zero for unconstrained funds. Constrained funds are funds that held less than 30\% weekly liquidity before the reform in 2009Q4. Unconstrained funds are the funds that held more than or equal to $30 \%$ weekly liquidity before the reform in 2009Q4. All funds that entered the sample only after the reform are classified as constrained or unconstrained as described in the definition of the $\mathrm{Con}_{\mathrm{f}}$ dummy in Appendix A.1. Size $\mathrm{ft}$ is the $\log$ of the net assets of a fund. All variables are winsorised at the $1^{\text {st }}$ and $99^{\text {th }}$ percentiles. In all regressions, the standard errors are clustered by funds (see Appendix A.1 for detailed definitions of all the variables). Significance levels are indicated by $* * * \mathrm{p}<0.01, * *$ $\mathrm{p}<0.05$ and $* \mathrm{p}<0.1$. 